\title{
Land betterment capture revisited: A methodology for territorial plans
}

\author{
Emília Malcata Rebelo ${ }^{\mathrm{a}, \mathrm{b}}$ \\ a Universidade do Porto, Faculdade de Engenharia, Rua Dr. Roberto Frias, s/n, 4200 - 465 PORTO, Portugal \\ b CITTA - Research Centre for Territory, Transports and Environment, Universidade do Porto, Portugal
}

\section{A R T I C L E I N F O}

\section{Keywords:}

Betterment

Value-capture

Developer obligations

Urban development costs and benefits

Equalisation mechanisms

Economic and financial sustainability

\begin{abstract}
A B S T R A C T
The main goal of this article consists in the proposal of a developer obligations' instrument aimed at capturing land betterments that result from planning decisions and from the implementation of territorial plans, reassigning them to public infrastructure, equipment and social purposes. It consists in charging for extra development rights beyond average municipal urban built-up areas. It is founded on a research and consultancy work for the Portuguese Territory Department (a governmental organism) within the scope of the revision of the Land Planning Act and complementary legislation, namely the new Juridical Regime of Urbanization and Edification, and the new Juridical Regime of Territorial Management Instruments. Thus herein are presented the assumptions, methodology, outcomes and conclusions of this work.

It is applied - as a case study - to the Detail Plan of Avenue Pope John XXIII, in Fátima (in the Municipality of Ourém, Portugal), but its application is generalizable to other municipalities, and it potentially strengthens their financial status.

Considering the current widespread crisis, and taking advantage from the experience of homologous value capture instruments in other countries, the proposed instrument is intended to contribute to strengthen municipal finance. It faces more clearly and objectively the funding of territorial planning and urban development. It further aims at developing understandable, quantifiable and user-friendly decision-support instruments, and at reassigning the betterments engendered by public planning decisions on behalf of communities.

This concept and methodology supports the consolidation of the objectives of the new Portuguese Land and Planning Act. It indeed fosters the integration of territorial policies, strengthens effectiveness in plan execution, supports the economic and financial sustainability of urban development operations, and promotes equity as well as social and territorial cohesion.
\end{abstract}

\section{Introduction}

All the legislation concerning land, territorial ordering and urban development was recently reviewed in Portugal. Thus the legislation currently enforced consists in the Portuguese Land and Planning Act (Law $n^{\circ} 31 / 2014$ ), the juridical regime of Territorial Management Instruments (Decree Law $n^{\circ} 80 / 2015$ ), the juridical regime of Urbanization and Edification (Decree law $n^{\circ} 136 / 2014$ ), and the new Cadastral Law. This revision is intended to surmount some drawbacks and inconsistencies that resulted from the application of the previous legislation. It conveys a new paradigm in land planning and management that stresses the relevance of the economic and financial sustainability of urban interventions. So they should only be approved if the incomes they are expected to engender surpass respective charges, according to a technical justification presented in proper urban plans.

The goals pursued in this new legislation consist in: improving the flexibility of urban plans, endowing municipalities with new planning instruments, securing the economic and financial feasibility of land use changes, controlling urban speculation and sharp rises in real estate prices, explaining betterment generation, defining and designing parameters for betterment reassignment on behalf of communities, and setting a municipal fund for urban and environmental sustainability (through collection of betterment values).

Within this scope, the current article proposes a new developer obligations' fiscal instrument of land policy that fits the new Land and Planning Act, and presents the methodoly for its computation. It proposes the partial recapture of the betterment arising from land use regulation that involves concrete building capacities higher than the municipal abstract average building capacitiy (computed from the parameters settled in Municipal Master Plans, Urban Development Plans, Detail Plans, parcelling out procedures, or other enforced territorial management instruments). ${ }^{1}$ This instrument is innovative in the

E-mail address: emalcata@fe.up.pt.

${ }^{1}$ Whenever the licensed building capacity $/ \mathrm{m}^{2}$ surpasses the average municipal building capacity $/ \mathrm{m}^{2}$, a $20 \%$ tax will focus upon this difference. On the contrary, if the building

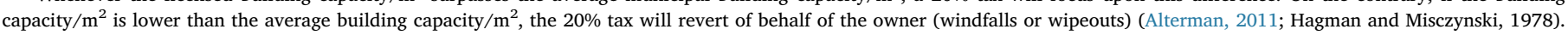


computation of average building capacities - called floor area ratio by some authors (Furtado and Bacellar, 2016). It is applied, as a case study, to the Detail Plan of Avenue Pope John XXIII, in Fátima (Legal warning $\left.n^{\circ} 15622 / 2009\right)$, Portugal.

\section{Theoretical framework}

Increases in land and property prices may result from its original productivity, owners' improvements, or broad changes such as population or local economic growth (Hong and Brubaker, 2010; Ingram and Hong, 2012; Walters, 2012a, 2012b). However, these values are most strongly shaped by infrastructure investments, provision of public services, and/or land planning and regulation (Alterman 2011, 2012; Ingram and Hong, 2012; Walters, 2012a, 2012b), namely licenses for certain land uses, or occupation densities (Smolka and Amborski, 2003).

Impacts of public investments, public services, or public land use on surrounding private land has been assessed both scientifically and empirically throughout last years (Ayougu, 2007; Bhatta and Drennan, 2003; Weber et al., 2003; Canning and Pedroni, 2008; Carroll, 2008; Haughwout, 2002; Mikelbank, 2004; Moreno and Lopez-Bazo, 2007; Siethoff and Kockelman, 2002; Smith and Gihring, 2006; Taylor and Brown, 2006; Walters, 2011, 2012a, 2012b).

However, land unearned increments are hard to compute, and even controversial, especially when land betterment precedes public action (Walters, 2012a), or result from land use regulation (Booth, 2003, 2012; Walters, 2012a).

Many authors stand up for land value capture (LVC) (George, 1962; Ingram and Hong, 2007; Netzer, 1998; Rebelo, 2009, 2012; Smolka and Amborski, 2007; Smolka and Furtado, 2003). These authors argue that part of betterments that result from land use regulation or from public investments, irrespective of owners' efforts, should be captured and reassigned on behalf of communities. They propose to use the collected income in urban infrastructure, public services, or even social housing (Alterman 2012; Brown and Smolka, 1997; England, 2007; Feinstein, 2012; Ingram and Hong, 2007; Lefebvre, 1991; Murphy, 2013; Netzer, 1998; Rebelo, 2014c, 2014d, 2014e, 2014g; Smolka and Amborski, 2003; United Nations, 1976; Walters, 2011, 2012a, 2012b). The Lincoln Institute of Land Policy (Smolka and Furtado, 2001), the International Academic Association on Planning, Law and Property Rights, the Global Land Tool Network (GNTL) and the UN_Habitat (Walters, 2011) have been working hard on this issues (Hendricks and Tonkin, 2010; Smolka and Amborski, 2003; Walters, 2012a, 2012b).

Land value capture instruments (Alterman 2011; Smolka and Amborski, 2007) may be classified in macro, direct or indirect instruments. Macro instruments consist either in land nationalization; substitution of private property by long-term public leaseholds (Bourassa and Hong, 2003; Hall, 1976); land banking (Atmer, 1987; Bourassa and Hong, 2003; Hall, 1976; Laanly and Renard, 1990; Strong, 1979) or land readjustment (Davy, 2007; Doebele, 1982; Needham and Hong, 2007). Indirect instruments are aimed at capturing unearned increments in order to fund specific public services. Direct instruments seek to capture rises in real property values, based on the rationale that landowners should share with the overall community the wealth generated by general economic or community conditions, public infrastructure, or land use plans or development decisions (Alterman, 2010; Skaburskis and Qadeer, 1992).

Value capture instruments are useful for many different reasons (Brown and Smolka, 1997; Walters, 2012a). They are economically efficient (Alexander et al., 2009; Netzer, 1998; Rebelo, 2009, 2012, 2014a, 2014b; Smolka and Amborski, 2007; Webb, 2013) and don't distort the real economy (Feinstein, 2012; Ko and Rosenblatt, 2013; Webb, 2013; Walters, 2011). They are further equitable (Ingram and Hong, 2012), useful to complement public funding, also benefit private partners (DGOTDU, 2011; Ingram and Hong, 2012; Ko and Rosenblatt, 2013), and tend to lower land prices and exert a more tight control over speculation (Alexander et al., 2009; Ingram and Hong, 2012; Rebelo, 2009, 2012, 2014a, 2014b; Webb, 2013; Walters, 2012a). They endow municipalities with financial means to support public services, infrastructure, equipment, and affordable housing (Alterman 2012; Rebelo, 2014f; Walters, 2012a) through the transference of part of their burden to developers, in return for the assignment of additional urban development rights, quick licence approval, or slacked regulation (Alterman, 2011). Besides, they don't increase building costs (Hong, 1998; Smolka and Amborski, 2003), harm citizens less than direct taxes (Alterman, 2012), and are easily taxable (Walters, 2011; Webb, 2013).

Many European countries stand up for the principle that urban development shouldn't bring about charges for municipalities. Its beneficiaries should support its burden instead, through agreements where charges and benefits of municipalities and private developers are settled (Cardoso et al., 2011). In the current scenario of public finance shortcomings, local decision makers in the United States of America and Europe have increasingly resorted to land value capture instruments to deal with decreasing incomes from traditional funding (Alterman, 1988; Altshuler and Gomez-Ibanez, 1993; Callies and Suarez, 2005; Ingram and Hong, 2012; Ko and Rosenblatt, 2013; Nelson et al., 2008; Rosenberg, 2006; Walters, 2012b).

Town property values depend on their location, dimension and licensed use, and the latter, by its turn, depends on public planning decisions and on territorial plans. Interventions to capture land betterment include fiscal devices, land use (namely re-zonings, assignment of additional building rights, or slacking in land use regulation), or through local improvements.

As far as betterment from land use regulation is concerned, Alterman (2010) carried out an extensive analysis of value capture instruments on many OECD countries (Australia, Austria, Canada, Finland, France, Greece, Germany, Israel, the Netherlands, Poland, Sweden, United Kingdom, and United States of America), covering many different geographic, legal, linguistic and cultural backgrounds. From these countries, the most experienced in land use regulation design and implemention (namely in land value capture) are the United Kingdom, Israel and Poland. The former, however, is the one with a soundest historical evolution that have long been concerned with financial sustainability (Table 1). The Spanish and the British experience in betterment capture is rather relevant, as these countries have largely influenced other outside countries (Alterman, 1982, 2011; Barker, 2004; Calavita and Mallach, 2009, among others). ${ }^{2}$

Worldwide legislation is profuse in developer obligations in order to recover, at least, part of the betterment values that accrue from public works, infrastructure, land use changes or land use intensities, through value capture. Such is the case of the United States of America Vermont and Pennsylvania states (Daniels et al., 1986; Gihring, 1999), Taiwan (Lam and Tsui, 1998), Hong Kong, and Singapore (Hui et al., 2004). The levied taxes, contributions, exactions, or regulations are a setback for zoning, assignment of (additional) building rights, or slackness in existing land use regulations (through which developers share their profits with the state or with the municipalities). These include "betterment levies" in the United Kingdom, in the United States of America, and in Latin American countries, "community infrastructure levies"; in the United Kingdom, "spatial development contributions" in

\footnotetext{
2 Barrett et al., 1979; Calavita et al., 2010; Capalbo, 2006; Crook et al., 2012; DenyerGreen, 1998; Dutch Government Administration; Fainstein, 2012; Federal Law 10257/ 2001; Furtado and Bacellar, 2016; German Law Archive; Gielen, 2008; Grant, 1999; Ingram and Hong, 2012; http://www.legislation.gov.uk; Lichfield and Darin-Drabkin, 1980; McAuslan, 1980; Ministère de ÍAménagement du Territoire, de la Ruralité et des Collectivités Territoriales; Morelli, 2007; Peterson, 2009; Rebelo, 2009; Tichelar, 2003; Williams and Hallett, 1988)

${ }^{3}$ The "Community Infrastructure Levies", which are collected on new building plans, are aimed at funding infrastructure construction or reinforcement that lack other funding means, thus ensuring its economic feasibility (http://www.legislation.gov.uk).
} 


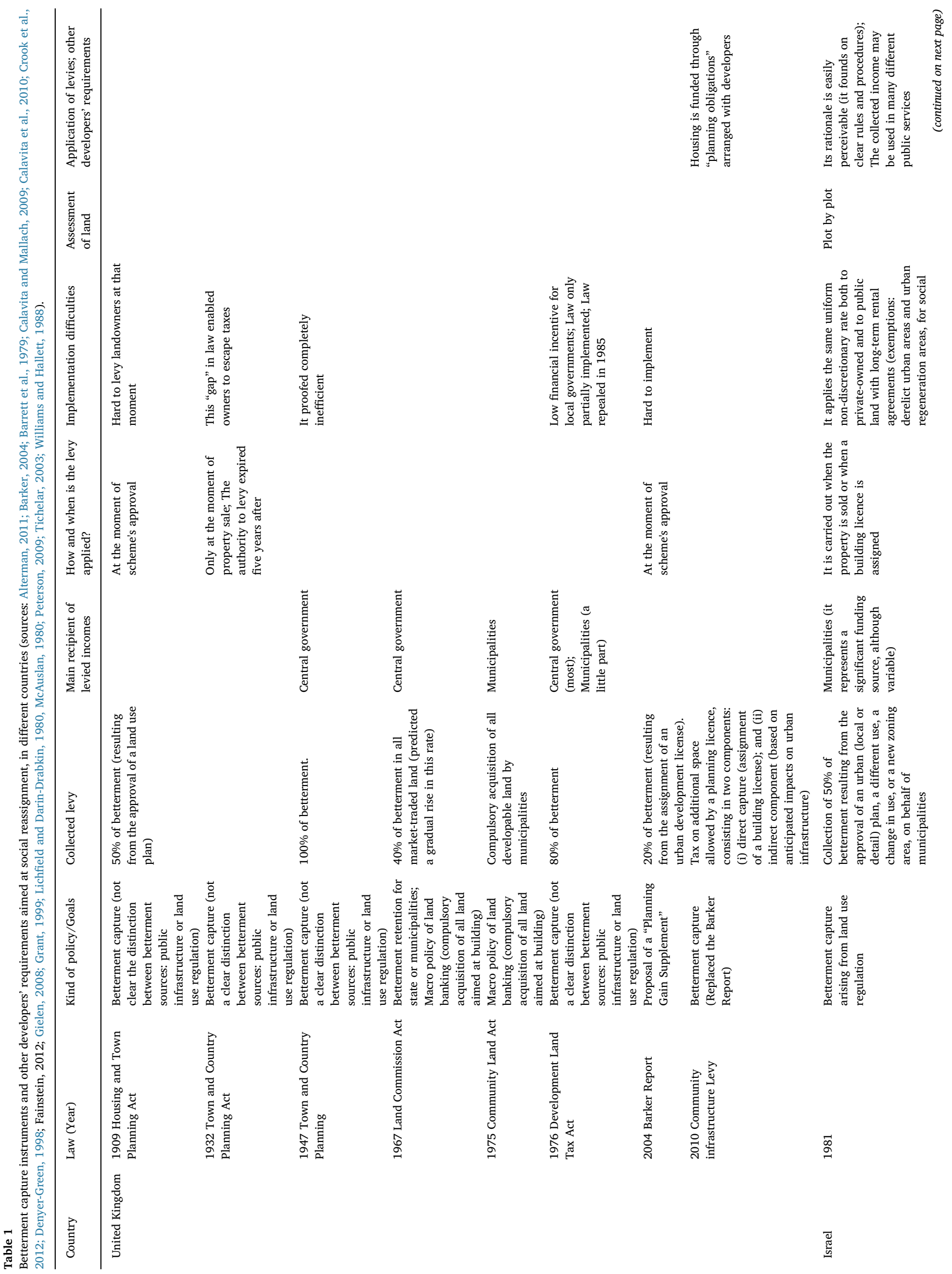




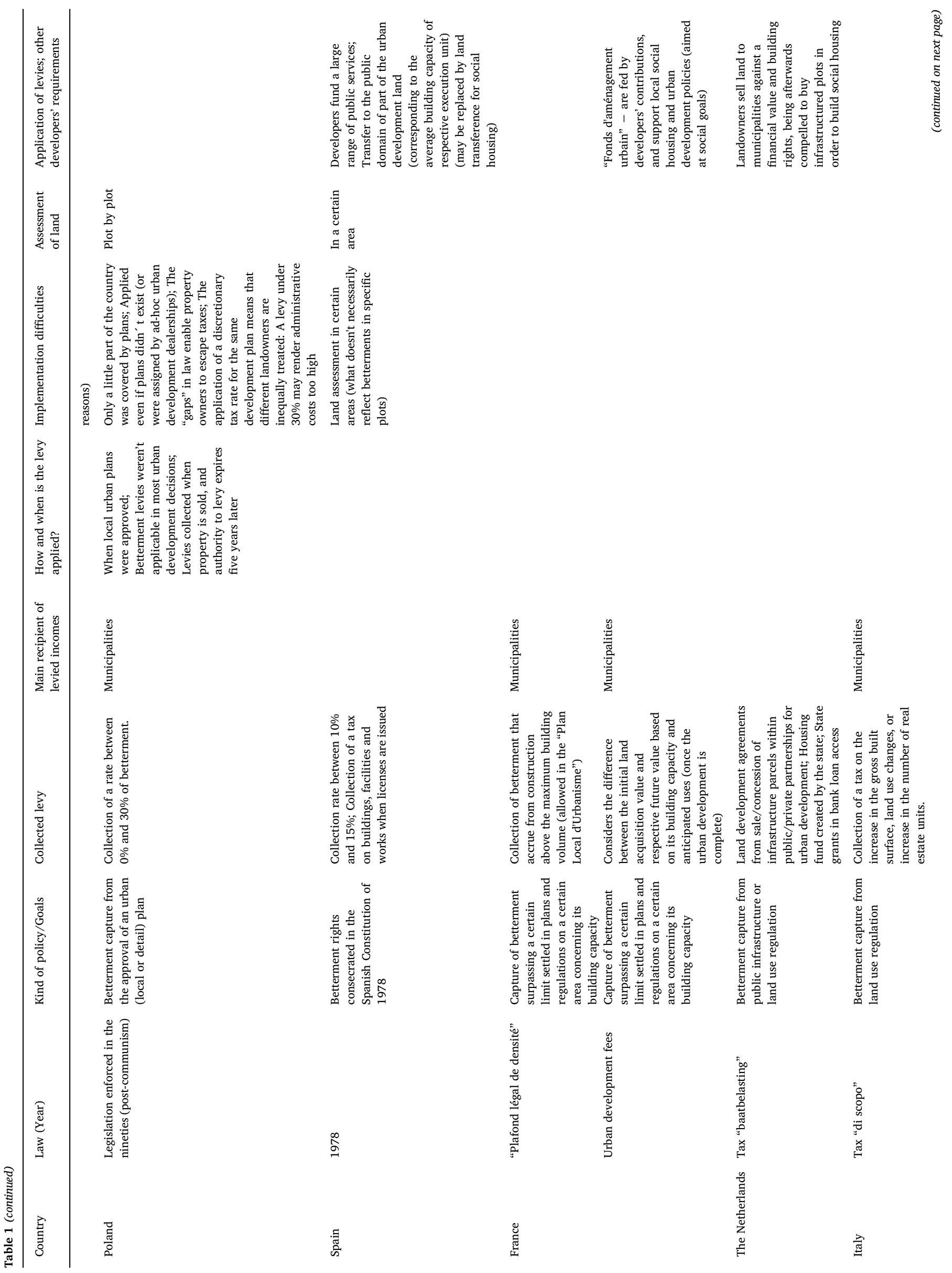


Germany, "di scopo"”; taxes in Italy, "tax d'ménagement" in France, "erschliessungsbeitrag" in Germany, "cargas de urbanización", "cesiones" and "reservas de suelo" in Spain, and "baatbelasting" and "exploitatiebijdrage" in the Netherlands (Gielen et al., 2015). These taxes generally focus on $30 \%$ to $60 \%$ of the registered increases in land values (Walters, 2012a). These "development obligations" found on national, regional or local laws that rule their scope through the definition of categories, patterns, or assessment parameters (Gielen et al., 2015). All these systems are based on contractual agreements, where private developers share their urban development's profits with the state (Booth, 2012; Ingram and Hong, 2012). They do not only cover part of infrastructure and equipment costs, but also contribute to support social needs, as this funding is mainly captured from land value increases induced by public planning decisions. In some European countries these contributions nourish funds aimed at social needs in general, or social housing in particular. These social-oriented funds are often complemented with other mechanisms. For instance in the Netherlands, besides land transference to the municipality, developers are compelled to buy infrastructured land plots later on to build social housing, in exchange for additional building rights. Municipalities in this country are backed by a fund to support social housing (that partially covers infrastructure costs), and they may be further awarded bank loan facilities (Dutch Government Administration). In France social housing is supported by the "Fonds d' aménagement Urbain". In Spain developers compulsorily transfer to public administration $5 \%$ to $15 \%$ of the average building capacity in respective execution unit to include in land public domain, despite this can be replaced by land transference aimed at social housing (Rodríguez, 2001).

In Spain - similarly to what happens in Portugal - the municipality can expropriate or use its own land parcels, or select a private developer (through open competition) to pursue infrastructure and building works. Developers support the urban development charges namely through the trust of developed parcels after land re-division into plots, and municipalities can ensure the operation's management. Besides, municipalities can further directly manage its own public land in order to achieve certain social targets, despite private developers can take on the whole operation's management, execution and funding (according to a compensation system) (Noticias Juridicas). Developers compulsorily transfer land plots for free to the municipality, carry urban development costs, and should additionally pay a tax on buildings, facilities and works ( $4 \%$ to $5 \%$ of respective costs) when licenses and other municipal fees are issued. They should further transfer to public administration part of the urban development use corresponding to the average building capacity of the execution unit, to integrate into the land public state property (usually between 5\% and 15\%), despite it can be replaced by land transfer aimed at social housing (Noticias Juridicas)

In France public infrastructure and equipment may be directly funded through the capture of betterments that accrue from the regulation of building capacities in that area (Ministère de l'Aménagement du Territoire, de la Ruralité et des Collectivités Territoriales). And it may further be indirectly funded through urban development fees that should cover public charges, considering the difference between land initial acquisition value and its future value once the urban development is complete (based on its building capacity and anticipated uses). The French "Plafond légal de densité", focus on the maximum licensed built area, above which the developer must pay the municipality for the excess of building capacity he has been awarded. This tax corresponds to the land value the developer should pay could he effectively build that intended building volume above the pre-settled "plafond légal de

\footnotetext{
${ }^{4}$ The "Tax di scopo" is a local tax that represents the percentage of unearned increments engendered by public works in respective area or bordering areas. This tax may focus on the gross built area, on the number of real estate units, or on changes in land uses, computed according to the average building cost in each region, on the one hand, and on urban development costs, on the other (Capalbo, 2006; Morelli, 2007).
} 
densité". It is similar to the Brasilian Municipal Charge on Building Rights, which is a fee on the excess of building capacity over a certain flor area ratio (Federal Law 10257/2001).

These instruments take different equalisation mechanisms in different European countries, such as the negotiation of building rights, exchange of land rights for building rights, transfer among individuals and/or in the scope of public-private partnerships, obligation to build social housing, or other social goals. In Germany, the Netherlands or Italy equalisation goals are achieved through the transference of building rights and building capacities among landowners in areas affected by public uses, where damages are compensated by profits engendered in the same or in another urban development operation (Mazza, 2005).

The main dimensions concerning the design and implementation of betterment levies among the most representative countries refer to the enforced laws; when and how levies are carried out (and difficulties in their implementation); main recipients of levied incomes (either central state or municipalities); how land is assessed (in a geographic region, in a specific area, or plot by plot); how levied incomes are applied; and developers' additional requirements for social-reassignment purposes) (Table 1).

\section{Materials and methods}

\subsection{Reasons for the development of the proposed instrument}

The developer obligations' instrument herein proposed is based on other homologous instruments existent in other countries. However, it tries to surmount some difficulties that emerged either from their concepts or from their practical application. It was elaborated as part of a consultancy and research work developed for the Portuguese Territory Department (a governmental organism), within the scope of the revision of land, planning and urban development legislation. It was, thus, fine-tuned to the Portuguese reality.

This proposal conveys a serious concern for a clear and objective quantification of building capacities. It stresses the importance to know the conceptualization of the new instrument, as well as the methodology that underlies its computation. The new Portuguese Land and Planning Act also requires qualitative and quantitative indicators to support land assessment, and the identification of available financial means in proposed urban development operations (through execution programmes and funding plans). In some European Countries and in some North American States and in Canada there exists a great accuracy in the definition of value capture instruments that apply similarly to all developers under the same circumstances, what supports a fairest levy. This issue strictly relates to discretionarity in tax application, what reflects subjective assessments (as in Poland, for instance).

In the current case the quantification of building capacities, first, and land prices and betterments afterwards, uses the values of urban parameters settled in enforced plans and in market town property transactions. An objective standardised and clear methodology is extensively reported, based on feasible institutional data, available for all municipalities, what renders the whole computation process easy and understandable. All these procedures may be easily implemented through computational routines, and harmonised with cartographic digital interfaces (that most municipalities already have or are still developing).

Despite the French "Plafond Légal de Densité" seemed to be a rather fair instrument, it failed to live upon its initial expectations, and engendered contradictory effects, that depended on municipalities and respective real estate markets (which are strongly interconnected with land use expectations). Indeed on the communes with weaker or reasonable land markets developers were discouraged to surpass the bound (the "plafond"), whereas communes subject to strong land pressures revealed able to engender income enough to fund the newly required infrastructure and equipment charges, so part of the betterment accrued by public decisions was effectively allocated on behalf of respective population. The instrument herein proposed tries to surmount that difficulty resorting to the use of the municipal average building potencial as a benchmark, according to the enforced plans in a certain municipality (also used at the regional level for the Italian "di scopo" tax). This average building capacity represents an original attempt to quantify the Flor Area Ratio (Furtado and Bacellar, 2016) keeping a fair balance among municipalities. The use of the average municipal building potencial keeps the leaning of municipal land uses (that fits previous and current urban plans), and promotes a more balanced development. The use of an endogenous benchmark matches proper municipal development processes, and conveys its intrinsic features, so it is better than any alternative external reference. It also prevents speculation processes as well as sharp price rises that could probably emerge from externaly-imposed expectations.

In what concerns the similarities with the "plafond legal de densité", the current proposal goes even further. So the above-average building capacity is now assessed from the perspective of the betterment engendered by public planning decisions. It is, thus, computed according to land values, instead of being computed strictly from areas. It represents a financial standardization of the equal distribution outcomes, so it is not expressed in physical terms - based on land plot shapes, location, characteristics and dimensions - but on its value (that is obviously shaped by all those factors). It implies the dematerialization of the levy, so it becomes easily comparable and quantifiable. So their subsequent assignments by the municipality also become more flexible, as cash income potentially covers a wider range of applications (namely investments in infrastructure, equipments, or social concerns - including social housing).

The long-standing experience of the United Kingdom stresses how important is the choice of the percentage of betterment that is recaptured by the public administration. It discloses how difficult it was for British governments to keep high rates. On the one hand, because it is hard to convey population the real meaning of these levies, despite people usually perceive them as usual taxes. On the other hand, because they confront the ongoing tradition of private property and private rights, representing a big threat for real estate and urban developmentrelated groups of interest. Thus a balance is urged in order to keep real estate markets alive and stimulate private initiatives, on the one side, and try to vindicate the principle that the capture of (part of) betterments that accrue from public decisions should belong to the community, on the other (where municipalities are in charge of collecting them). It should't be forgotten that urban development iniciatives are important sources of municipal income and community welfare through taxes, fees, and the provision of other benefits to communities (including public services, infrastructure, equipment, and many socialoriented outcomes). It is also important to recognise the importance for political decision-makers of the existence of manoeuvre margins, so they can technicaly anchor their decisions, despite feeling free to choose amongst a range of possible alternatives. So based on the British experience and on the Portuguese similar reality on these grounds, it seems reasonable the adoption of a $20 \%$ of betterments to be captured by public organisms (considering the results of the British implementation of similar instruments, despite with a range of different rates, and varying territorial outreaches). This rate is settled in order not to discourage the private initiative and to promote trade (it fits a lenient environment towards private appropriation). It complements indirect capture mechanisms, and takes into account zoning specifications, as well as building costs and expected market prices (what adjusts to the context of betterment capture application).

According to the studied instruments (Table 1), in some cases levies go to central governments and in other cases to municipalities. The experience in the corresponding countries generally shows that the closer the application of levies is to the citizens, the better is their support because they apprehend place and time nearness as advantageous for their own interests. So municipalities are intended to apply 
the instrument herein presented, and levies should straightly revert to them. They are expected to publicly present in advance a proposal for the application of levied incomes.

It is also important to settle the outreach of the instrument. In which situations should it be levied? It seems consensual from the analysis of existing homologous instruments that levies should be applied whenever land use changes take place, when licenses to build above certain parameters are assigned, when a general or detail plan for a certain area is enforced, and in all the situations that can potentially engender rise in land prices. Is it applicable to already enforced plans or, on the contrary, can its application be extended to future plans what, inevitably, risks engendering speculation and price raises? This issue is strictly related to the moment of levy: literature and experience point out difficulties in any moment. However, in the current case it is proposed its application to approved plans when urban development licenses are endowed. It is addressed to developers, promoters and builders that should pay municipalities lump-sum upfront payments, at the moment of the approval of a certain plan, as a counterweight to the endowment of licenses over average municipal building potential (according to applicable plans). It seems to be a wise solution, as it grasps control over anticipated speculation that accrues from land use changes or intensities.

Finaly, how should be applied the levies thus collected? It diverges according to the analised countries. Its contribution to the municipal budget in the studied case varies between $1 \%$ and $4,4 \%$ for four-year investment periods. This fact stresses its importance for municipal finance, and opens up a range of possible applications, thus responding to different goals, from infrastructure construction, reinforcement and maintenance, to social housing. Most important, however, is that they enable political decision-makers to anticipate their applications and assigned amounts in provisional documents (plans and budgets) they should make available beforehand. It is also important that these decisions are harmonised with other sources of municipal incomes, and respective anticipated applications. It can be deduced from practical situations that the best citizens are informed on the application of the public money, the stronger will be their adhesion to municipal decisions.

It is also important to stress the concern with simplicity in implementation, adopted ever since the beginning of this developers' obligation proposal.

\subsection{Rationale of the proposed methodology}

The concept underlying the value capture instrument herein presented is that developers, promoters and/or builders should pay the municipality a certain amount of cash as a counterpart for the licence settled in plans - to build over a specific construction level. The proposed developers' obligation consists in charging a $20 \%$ tax on land betterment values derived from a concrete building right higher than the average municipal building capacity.

To reach this goal it is necessary, first, to assess the amount of betterments that accrue from the plan's approval. This is done through the computation of the gross built area per $\mathrm{m}^{2}$ of land in a certain development operation, and its comparison with the average municipal gross build area per $\mathrm{m}^{2}$ of land, considering the urban parameters applicable and the different areas where they are enforced. This diference between the licensed building areas and the average municipal building area per $\mathrm{m}^{2}$ of land is then valued, using the difference between the range of land market prices - based on registered transactions of urban land - and the corresponding values of urban land that result from the application of the Real Estate Municipal Tax Code (according to the characteristics of property plots, namely their shapes, location, dimension and other characteristics). The obtained values - for the different specified areas, according to the applicable plans - represent the assessed betterments derived from the implementation of a specific plan (from the construction of a specific level of licensed building areas). Then the rate of $20 \%$ is applied on these assessed betterments.

So the different stages of this methodology consist in the determination of the average municipal building capacity $/ \mathrm{m}^{2}$; the concrete building capacity $/ \mathrm{m}^{2}$ assigned to specific urban interventions; the land value range based on market transactions; the land value for the different areas according to the real estate tax code; the betterment value that accrues from the Detailed Plan (or other applicable territorial plans or granted licenses); and the potential taxable value that results from the application of this new developer obligations' instrument.
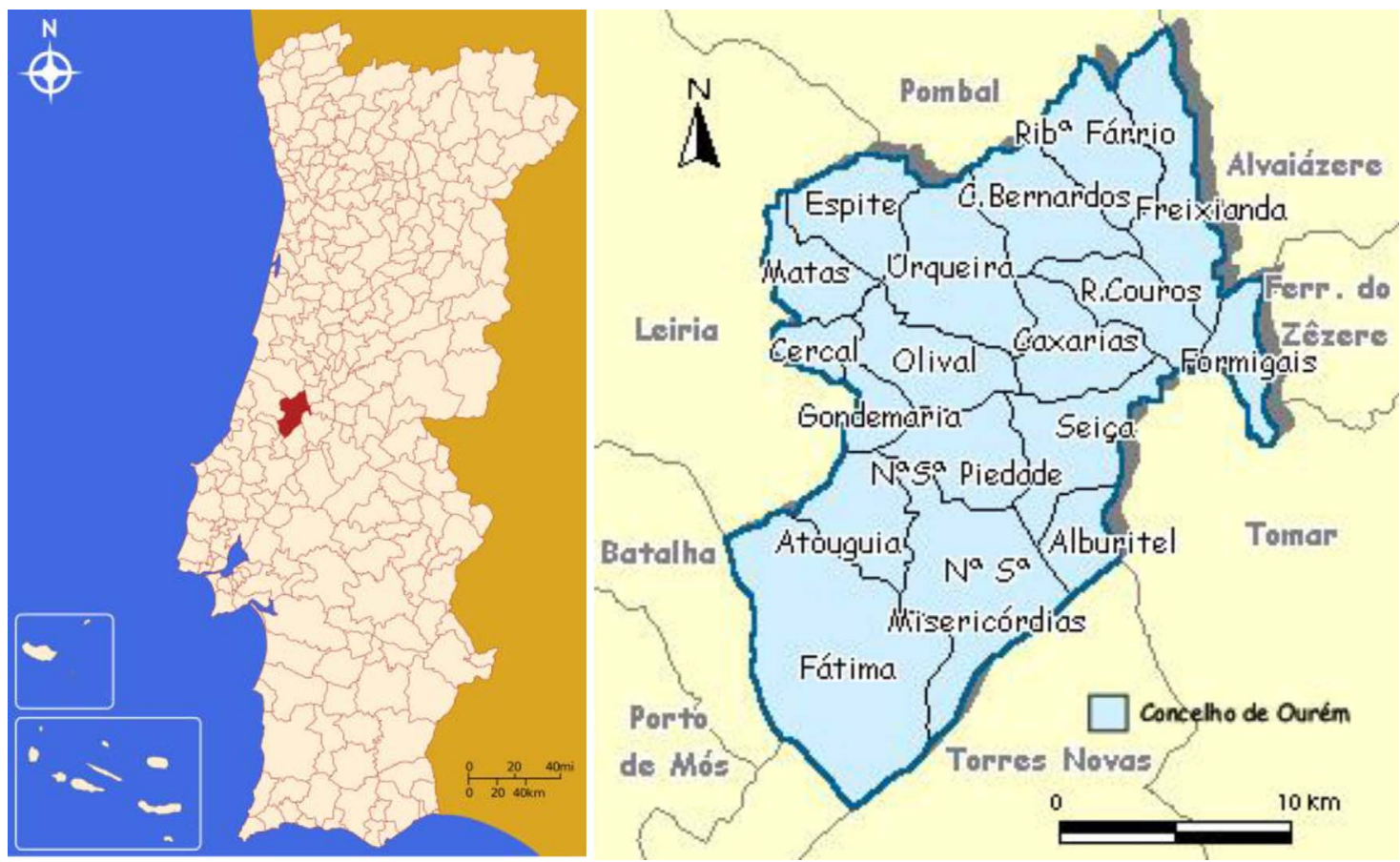

Fig. 1. Map of the municipality of Ourém: its location in continental Portugal, and respective parishes (source: https://www.google.pt/; Grupo Marktest). 


\section{Case study}

The municipality of Ourém locates in the Portuguese region of Lisbon and Tagus Valley - near the central region - in the district of Santarém. It is $140 \mathrm{~km}$ away from Lisbon, $200 \mathrm{Km}$ away from Porto, and $50 \mathrm{~km}$ away from the coast. It spans a surface of about $417 \mathrm{~km}^{2}$, is made up by 18 parishes, and has a population density of 98.2 inhabitants $/ \mathrm{km}^{2}$ (Fig. 1).

Fátima is the administrative centre of the homologous parish that belongs to the municipality of Ourém. This town - that spans a surface of 71,29 $\mathrm{km}^{2}$ - lodges 11596 inhabitants (INE, 2011a), and has a population density of 162,7 inhabitants $/ \mathrm{km}^{2}$. It is, together with Leiria town, the seat of Leiria diocese.

Fátima is an internationally and nationally well-known centre for religious reasons connected to Our Lady of Fátima's worship.

\subsection{Territorial planning instruments enforced in the municipality of Ourém}

\subsubsection{Urban development plan of Fátima}

The pilgrimage nature of Fátima have shaped its urban structure as well as its planning processes throughout the last century. The recently revised Urban Development Plan of Fátima (Governmental order $\mathrm{n}^{\circ}$ 633/95; Resolution of the cabinet council n. ${ }^{\circ} 148-\mathrm{B} / 2002$; Legal warning $n .^{\circ} 2766 / 2009$; Legal warning $n .^{\circ} 18200 / 2009$; Legal warning n. $\left.{ }^{\circ} 6992 / 2015\right)$ suits better its current reality. It, indeed, settles a more efficient frame for urban development, namely through more appropriate rules and solutions (Correia et al., 2001; Lopes et al., 2014). This development plan resorted to Detail Plans to work out its solutions, especially in denser planning and management subunits. It also took advantage of complementary analysis of traffic and parking, considering the exceptional car flows during pilgrimages (Correia et al., 2001; Lopes et al., 2014).

The management model currently implemented ensures the feasibility of the proposals settled in applicable plans, namely on infrastructure and equipment grounds, considering the kind of urban development enleashed by Fátima religious events. Negotiated agreements are settled either within the public administration, or among the municipality and private stakeholders in order to assure that anticipated urban interventions are efficient and kept in time (Correia et al., 2001; Lopes et al., 2014).

\subsubsection{Municipal Master Plan of Ourém}

Municipal planning and urban development in the whole municipality of Ourém are framed by its Municipal Master Plan (Resolution of the cabinet council n. ${ }^{\circ}$ 148-A/2002; Legal warning n. ${ }^{\circ}$ 5416/2009; Legal warning n. $18200 / 2009$; Legal warning $n .^{\circ} 11779 / 2010$; Rectification Declaration n. ${ }^{\circ} 1614 / 2010$; Legal warning n ${ }^{\circ} 7841 / 2011$; Legal warning n. ${ }^{\circ}$ 4800/2013; Legal warning $n .^{\circ}$ 4735/2013;
Rectification declaration n. $\left.{ }^{\circ} 485 / 2015\right)$. It provides the main guidelines for the application of urban development and detail plans.

This Municipal Master Plan resorted to digital cartography, to ongoing monitoring, and to participatory decision-processes (Correia et al., 2002). Digital cartography supports a swift characterization, diagnosis and implementation of plans, and reconciles planning constraints with land changes more accurately. Ongoing monitoring supports anticipated identification of problems, pointing out for inflections at the right time. Different stakeholders have tried to harmonise their different interests through shared decision processes.

According to this plan, municipal urban developed or developable spaces rank into level 1, 2, or 3 subcategories of urban spaces. Level 1 encompasses built-up urban areas with trade, services and equipment functions at municipal and above municipal grounds; level 2 includes built-up urban areas or sets of areas with trade, services and equipment functions at local grounds; whereas level 3 comprises the remaining built-up areas or sets of areas. The urban perimeters of the towns of Ourém and Fátima include level 1 built-up urban areas.

The areas of Fátima covered either by the Detail Plan of Avenue Pope John XXIII (Legal warning $n^{\circ} 15622 / 2009$ ) or by the Detail Plan for the block formed by Francisco Marto Road, Lomba de Égua Street and Market Road (Governmental order $n^{\circ}$ 67/99) are guided by respective urban parameters. The same is true for the Detail Plans enforced inside the urban perimeter of Ourém: the Detail Plan of the industrial area of Casal dos Frades (Resolution $n^{\circ}$ 195/91), the Detail Plan of the Health Centre of Ourém (Governmental order $n^{\circ} 190 / 97$ ), the Detail Plan of Caridade (Governmental order $n^{\circ} 496 / 93$; Governmental order n ${ }^{\circ}$ 445/97; Declaration n ${ }^{\circ} 376 / 99$ ), and the Detail Plan of Quinta do Ribeirinho (Resolution of the cabinet council $n^{\circ} 159 / 2000$ ).

The remaining areas of Fátima which are not covered neither by Detail Plans nor by the Urban Development Plan of Fátima, and the remaining areas of Ourém not covered by Detail Plans are subject the precepts of the Municipal Master Plan.

\subsubsection{Detail Plan of Avenue Pope John XXIII}

The Detail Plan of Avenue Pope John XXIII pursues a set of urban development goals. First of all it seeks to strengthen the global image of Fátima, preserving and valuing its symbolic spaces and their environment. Secondly it settles guides for a balanced urban and architectonic order. It also aims at shrinking the dichotomy between the sanctuary and its surrounding area, thus searching for complementarity and coherence in the whole, and at developing a civic centre near the Sanctuary aimed at local inhabitants (regardless of pilgrimage movements).

The urban design proposed in this plan balances built areas and outside spaces, rules land infrastructure, occupation and use, and designs a network of public spaces, jointed together with already existing ones (Terraforma and José Lamas e Associados, 2009). It further

Table 2

Proposal for the occupation of the urban development units of the Detail Plan of Avenue Pope John XXIII source: Terraforma and José Lamas e Associados, 2009.

\begin{tabular}{|c|c|c|c|c|c|c|c|c|c|c|}
\hline $\begin{array}{l}\text { Urban } \\
\text { development } \\
\text { units }\end{array}$ & $\begin{array}{l}\text { Plots: housing, } \\
\text { trade, services } \\
\text { and tourism } \\
\left(\mathrm{m}^{2}\right)\end{array}$ & $\begin{array}{l}\text { Equip./ } \\
\text { religious } \\
\text { buildings }\left(\mathrm{m}^{2}\right)\end{array}$ & $\begin{array}{l}\text { Colletive } \\
\text { equipment } \\
\left(\mathrm{m}^{2}\right)\end{array}$ & $\begin{array}{l}\text { Roads and } \\
\text { car parks } \\
\left(\mathrm{m}^{2}\right)\end{array}$ & $\begin{array}{l}\text { Big car } \\
\text { parks } \\
\left(\mathrm{m}^{2}\right)\end{array}$ & $\begin{array}{l}\text { Pavements and } \\
\text { staying spaces } \\
\left(\mathrm{m}^{2}\right)\end{array}$ & $\begin{array}{l}\text { Collective use } \\
\text { spaces }\left(\mathrm{m}^{2}\right)\end{array}$ & $\begin{array}{l}\text { Collective } \\
\text { spaces with } \\
\text { project }\left(\mathrm{m}^{2}\right)\end{array}$ & $\begin{array}{l}\text { Big green } \\
\text { parks }\left(\mathrm{m}^{2}\right)\end{array}$ & TOTAL $\left(\mathrm{m}^{2}\right)$ \\
\hline A & 28905 & & 9371 & 60302 & 30122 & 41346 & 30027 & & & 200073 \\
\hline B & & 41750 & & 16779 & 15353 & 36103 & 40348 & 43171 & & 193504 \\
\hline $\mathrm{C}$ & & 11406 & & 17624 & 14890 & 17596 & 8522 & 1973 & 52335 & 124346 \\
\hline $\mathrm{D}$ & 56068 & & & 51790 & & 42441 & 12645 & 1598 & & 164542 \\
\hline E & 38071 & & & 20892 & & 8439 & 20148 & 1470 & & 89020 \\
\hline $\mathrm{F}$ & 19710 & & & 18724 & & 11453 & 4925 & 2640 & & 57452 \\
\hline G & & & & 5042 & & 9691 & 5355 & & 49338 & 69426 \\
\hline $\mathrm{H}$ & 23880 & & & 21175 & & 16257 & 3188 & & & 64500 \\
\hline I & 44861 & & & 15331 & & 8844 & 4914 & & & 73950 \\
\hline TOTAL & 211495 & 53156 & 9371 & 227659 & 60365 & 192170 & 130072 & 50852 & 101673 & 1036813 \\
\hline
\end{tabular}


develops proposals already settled in the Urban Development Plan of Fátima, designs and integrates urban forms within the current and proposed urban structure, and reinforces housing, touristic and services functions. It additionally settles a green structure that includes equipment and leisure, frames the requalification of the road network, adjusts already built or assigned plots, and states agreements for urban development. It finally provides equalisation mechanisms in benefits' and charges' distribution; sets aside plots of land assigned to equipment's future location, and controls car parking.

Table 2 as follows, features the land occupation proposal. Figs. 2

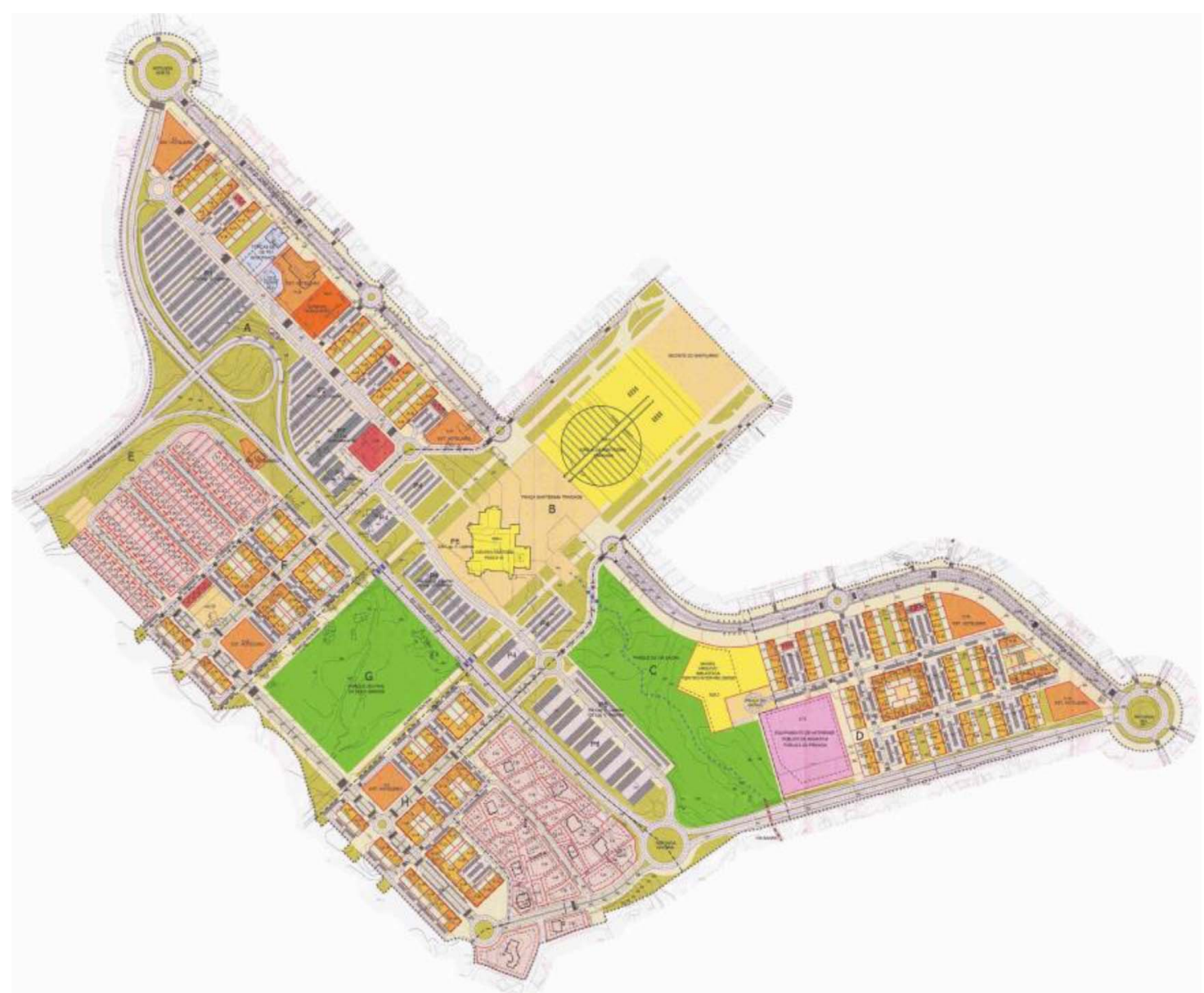

\section{Land and buildings' uses}

HOUSING (I)

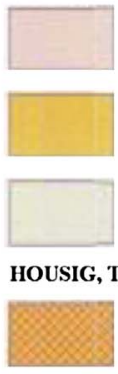

Single or bi-family house (2 floreys)

Multi-family buildings ( 4 and 5 floreys)

Public place of multi-family buildings

ADE AND/OR SERVICES (H/T/S)

Multi-family buil with trade and/or services in the ground floor

OUTSIDE URBAN SPACES AND GREEN SPACES

Collective-use spaces

Parks with specific projects assigned

Collective-use outsider spaces with specific projects assigned

\section{TRADE AND/OR SERVICES (T/S) RQUIPMENT}

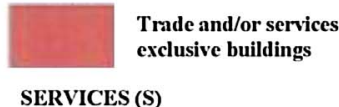

Public and private public-

SERVICES (S) interest equipment

\section{TOURISM (T)}

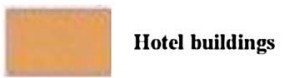

ROAD AND TRANSPORTATION NETWORK
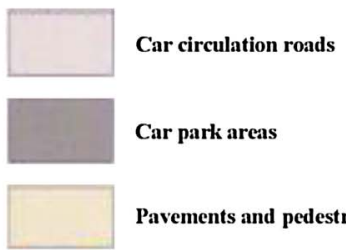

Pavements and pedestrian recints

Transport infrastructure

Fig. 2. Implantation Plan settled in the Detail Plan of Avenue Pope John XXIII (source: http://www.dgterritorio.pt/). 


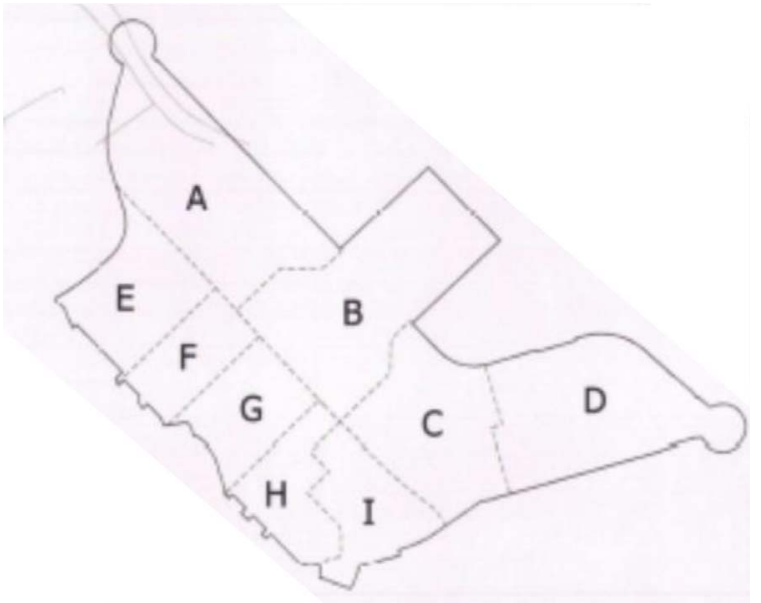

Fig. 3. Urban development units previewed in the Detail Plan of Avenue Pope John XXIII (source: http://www.dgterritorio.pt/).

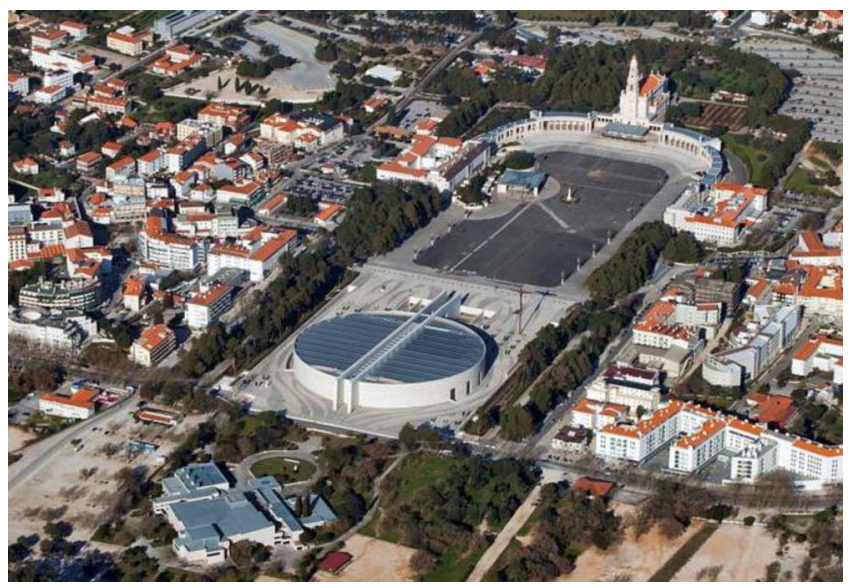

Fig. 4. The urban space that resulted from the implementation of the Detail Plan of Avenue Pope John XXIII (source: www.google.com).

and 3 present the implantation plan, and its respective subdivision into urban development units (Source: Legal warning $n^{\circ} 15622 / 2009$ ). Fig. 4 pictures the urban space that resulted from the implementation of the Detail Plan Pope John XXIII.

\subsection{Computation of the average municipal building capacity $/ \mathrm{m}^{2}$}

The average municipal building potential $/ \mathrm{m}^{2}$ represents the gross built surface (expressed in $\mathrm{m}^{2}$ ) allowed by enforced territorial plans per $\mathrm{m}^{2}$ of land in the whole municipality. It is computed through the sum extended to the whole municipal developed and developable area - of the areas where urban parameters of different planning tools apply, multiplied by respective occupation indexes (quotient between the implantation and land areas, expressed in \%) and land use indexes (quotient between the total gross built area and the land area, expressed in $\mathrm{m}^{2}$ per $\mathrm{m}^{2}$ of land), multiplied by the percentages assigned to each kind of use.

Within the applicable legal and regulatory framework, the following methodology was pursued in the computation of the average building potential $/ \mathrm{m}^{2}$ of Ourém (Rebelo, 2014e):

- Identification of the areas encompassed by the urban perimeter of Fátima, where the Urban Development Plan of Fátima is enforced;

- Identification of the areas encompassed by the urban perimeter of Ourém (level 1 built-up areas), where the Municipal Master Plan of Ourém is enforced;

- Identification of the areas inside the urban perimeter of Fátima where the Detail Plans are enforced: Detail Plan of Avenue Pope John XXIII and Detail Plan for the block formed by Francisco Marto Street, Lomba de Égua Road and Mercado Street;

- Identification of the areas inside the urban perimeter of Ourém where the Detail Plans are enforced: Detail Plan of the industrial area of Casal dos Frades; Detail Plan of the Health Centre of Ourém; Detail Plan of Caridade; and Detail Plan of Quinta do Ribeirinho;

- Identification of level 2 and 3 built-up urban areas in the municipality of Ourém, where the Municipal Master Plan is enforced;

- Application of the corresponding urban parameters (according to the enforced plans) in each previously identified area, in order to set up respective maximum allowed gross built areas;

- Computation, for each area, of the concrete gross built area $/ \mathrm{m}^{2}$, through the quotient between the maximum allowed gross built area and respective territorial area (expressed in $\mathrm{m}^{2} / \mathrm{m}^{2}$ of land);

- Determination of the percentage of each of these areas in relation to the total developed and developable urban area in the municipality of Ourém;

- Computation of the average gross built area $/ \mathrm{m}^{2}$ through the sum total extended to all considered territorial areas, of the product between respective percentages in relation to the whole studied developed and developable space, and the corresponding gross built areas.

The average municipal building potential $/ \mathrm{m}^{2}$ in urban developed and developable areas in the municipality of Ourém amounts, therefore, to $0.1716 \mathrm{~m}^{2} / \mathrm{m}^{2}$ of land, multiplying the different studied gross built areas by respective percentages in relation to the total developed and developable municipal urban area (Rebelo, 2014e) (Table 3).

\subsection{Computation of the range of the average municipal market price $/ \mathrm{m}^{2}$}

The average annual gross built area was first computed for the municipality of Ourém, in order to assess the range of average municipal prices $/ \mathrm{m}^{2}$ based on market transactions (INE, 2009, 2010, 2011b, 2012) (Table 4). In this computation were considered the latest four years provided with available data from the National Statistics Institute and from municipal sources, in order to prevent fluctuations depending on the situation. The period considered might vary, according to stability/changeability in building works (including economic general/ local conditions, public investments, urban or industrial operations, population growth/reduction, or new infrastructure, equipment or public spaces), or to prices.

Table 3

Synthesis of the gross built areas $/ \mathrm{m}^{2}$ of the different delimited areas in the municipality of Ourém, and abstract average municipal building area/m $\mathrm{m}^{2}$ in the whole municipality source: author

\begin{tabular}{|c|c|c|c|}
\hline & Area $\left(\mathrm{m}^{2}\right)$ & $\%$ of area in relation to the total area & Gross built area/m $\mathrm{m}^{2}$ \\
\hline Total area inside the urban perimeter of Fátima & 9830000 & $15.00 \%$ & 0.4262 \\
\hline Total area inside the urban perimeter of Ourém & 3952000 & $6.03 \%$ & 0.6119 \\
\hline Developed and developable urban area of level 2 built-up urban areas $\left(\mathrm{m}^{2}\right)$ & 22444000 & $34.25 \%$ & 0.1125 \\
\hline Developed and developable urban area of level 3 built-up urban areas $\left(\mathrm{m}^{2}\right)$ & 29307000 & $44.72 \%$ & 0.0720 \\
\hline Total developed and developable urban area of the municipality of Ourém & 65533000 & $100.00 \%$ & 0.1716 \\
\hline
\end{tabular}


Table 4

Estimation of the average annual gross built area of the municipality of Ourém for 2008, 2009, 2010 and 2011, and corresponding annual average value source: INE, 2009, 2010, 2011b, 2012; author

\begin{tabular}{|c|c|c|c|c|c|c|}
\hline & 2008 & 2009 & 2010 & 2011 & Total & Average \\
\hline Total number of finished buildings [1] & 345 & 276 & 246 & 258 & 1.125 & 281 \\
\hline Average number of storeys per building [2] & 2.6 & 2.3 & 2.2 & 2.2 & 9.3 & 2.3 \\
\hline Average number of dwellings per storey [3] & 0.7 & 0.6 & 0.6 & 0.7 & 2.6 & 0.7 \\
\hline Average number of compartments per building [4] & 5.2 & 5.7 & 5.7 & 5.3 & 21.9 & 5.5 \\
\hline Average livable surface per compartment $\left(\mathrm{m}^{2}\right)[5]$ & 19.957 & 21.500 & 21.3 & 20.8 & 83.6 & 20.9 \\
\hline Total gross built surface $\left(\mathrm{m}^{2}\right)[6]=[1] \times[2] \times[3] \times[4] \times[5] / 0.65$ & 106481 & 71811 & 60653 & 67385 & 306329 & 76582 \\
\hline
\end{tabular}

Table 5

Estimation of the average lower and upper limits of land prices $/ \mathrm{m}^{2}$ in the municipality of Ourém for $2008,2009,2010$ and 2011 , and corresponding annual average values source: INE, 2009, 2010, 2011b, 2012; author

\begin{tabular}{|c|c|c|c|c|c|c|}
\hline & 2008 & 2009 & 2010 & 2011 & Total & Annual average \\
\hline Total value of urban land plot transactions $(€)[1]$ & 58065000 & 41098000 & 45109000 & 23630000 & 167902000 & 41975500 \\
\hline Gross built area $\left(\mathrm{m}^{2}\right)[2]$ & 106481 & 71811 & 60653 & 67385 & 306329 & 76582 \\
\hline Maximum land area underlying the gross built area $\left(\mathrm{m}^{2}\right)[3]=[2] / 0.1716$ & 620517 & 418476 & 353454 & 392689 & 1785136 & 446284 \\
\hline Minimum land area underlying the gross built area $\left(\mathrm{m}^{2}\right)[4]=[2] / 0.4795$ & 222066 & 149761 & 126492 & 140533 & 638852 & 159713 \\
\hline Minimum value of urban land plot transactions $/ \mathrm{m}^{2}$ of land $(€ / \mathrm{m})[5]=[1] /[3]$ & 94 & 98 & 128 & 60 & 380 & 95 \\
\hline Maximum value of urban land plot transactions $/ \mathrm{m}^{2}$ of land $(€ / \mathrm{m})[6]=[1] /[4]$ & 261 & 274 & 357 & 168 & 1061 & 265 \\
\hline
\end{tabular}

This built area was computed considering the total number of buildings erected each year in the studied municipality. Offices and other services were supposed to occupy, on average, surfaces similar to dwelling uses, what seems reasonable for most cases.

In the computation of the average gross built area were pursued the following steps:

- Collection of statistical data concerning the total number of buildings concluded annually [1] (new construction, and buildings' enlargement, changes or reconstruction) for a four-year period.

- Estimation of the total liveable area for urban uses $\left(\mathrm{m}^{2}\right)$, reckoned through the product among the total number of buildings concluded annually [1], the average number of floors per building [2], the average number of dwellings per floor [3], the average number of compartments per dwelling [4], and the average liveable surface per room (expressed in $\mathrm{m}^{2}$ ) [5].

- The total gross built area $\left(\mathrm{m}^{2}\right)[6]$ is, thus, approached through the division of the total average liveable area by 0.65 (considering that the liveable area usually amounts to approximately $65 \%$ of the gross surface).

The average market land price $/ \mathrm{m}^{2}$ in the whole municipality is determined through the quotient between the value of the annual average town property trade and the land surface underlying the effective annual average gross built surface, according to the average municipal building capacity $/ \mathrm{m}^{2}$.

Average land prices $/ \mathrm{m}^{2}$ were estimated from total transaction values of urban estates (as they amount to more than $90 \%$ of transaction values of total estates - urban, rural or mixed). An estate is urban if it licensed for housing, trade, industry or services, or if it locates in a build-up urban area licensed for land plot division or construction. This concept excludes land plots where those operations are forbidden (namely those located on green/preserved areas or assigned to infrastructure or equipment).

The accurate price depends not only on the total amount of annual gross built area, but also on its geographic distribution (according to respective licensed urban parameters). Thus the lower limit of variation of market transaction prices correspond to the use of all developed and developable municipal area, whereas the upper limit considers that all gross built surface is erected in level 1 urban areas. The latter assumption reasonably fits reality, considering that most urban developments take place in these built-up areas.

The swiftness and efficiency in price computation may be improved through the collection of additional data (resorting to surveys, for instance), or through the development/implementation of a management information system (with a cartographic interface) that assigns the gross built areas to the places where they effectively belong.

The range of the average land price $/ \mathrm{m}^{2}$ based on market town property transactions of the municipality of Ourém was computed as follows, for each considered year (INE, 2009, 2010, 2011b, 2012) (Table 5):

- Collection (from the Statistical Yearbooks of the central region) of the total amounts of town property traded during 2008, 2009, 2010 and $2011(€)$ [1];

- In order to compute the range of land prices $/ \mathrm{m}^{2}$, built areas were expressed as a function of land underlying surfaces $\left(\mathrm{m}^{2}\right)$. In the current case it was considered as the lower limit the situation where the whole gross built area locates throughout the developed and developable urban area (where the average gross built surface is $0.1716 \mathrm{~m}^{2} / \mathrm{m}^{2}$ of land), and as the upper limit the situation where the whole gross built surface only takes place in level 1 urban areas (where the average gross built surface amounts to $0.4975 \mathrm{~m}^{2} / \mathrm{m}^{2}$ of land, using the computation methodology previously described). ${ }^{5}$ The corresponding maximum [3] and minimum [4] limits of surface land underlying those gross built areas are, then, determined through the quotient between the gross built areas [2] and corresponding building capacities;

- Finally, the lower [5] and upper [6] limits for the average land price $/ \mathrm{m}^{2}$ are given by the quotient between the value of town property transactions [1] and land surfaces that underlie respective gross built areas [3] or [4].

\subsection{Computation of $20 \%$ of betterment values that accrue from the implementation of the Detail Plan of Avenue Pope John XXIII}

Thus the average annual land transaction price based on market

\footnotetext{
5 The total surface of level 1 urban areas in the municipality of Ourém amounts to $13782000 \mathrm{~m}^{2}$, being $9830000 \mathrm{~m}^{2}$ in the urban area of Fátima $(71.32 \%)$ and $3952000 \mathrm{~m}^{2}$ in the urban area of Ourém (28.68\%). Thus weighing the gross built surface per $\mathrm{m}^{2}$ of land leads to an average value of $0.4795 \mathrm{~m}^{2} / \mathrm{m}^{2}$ of land in level 1 urban areas $(0.4262 \times 71.32 \%+0.6119 \times 28.68 \%)$
} 
Table 6

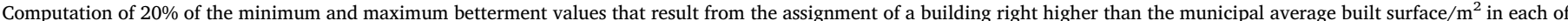
the urban development units of the Detail Plan of Avenue Pope John XXIII, in Fátima

source: author

\begin{tabular}{|c|c|c|c|c|c|c|c|c|c|}
\hline Units & & & Unit A & Unit D & Unit E & Unit F & Unit $\mathrm{H}$ & Unit I & $\begin{array}{l}\text { Total Detail } \\
\text { Plan }\end{array}$ \\
\hline Surface of the urban development units $\left(\mathrm{m}^{2}\right)$ [1] & & & 28905.2 & 56068.2 & 38071.0 & 19710.0 & 23880.0 & 44861.1 & 211495.6 \\
\hline \multirow[t]{4}{*}{ Maximum gross built surface $\left(\mathrm{m}^{2}\right)[2]$} & TOTAL & & 63703 & 141608 & 22436 & 60370 & 73155 & 12775 & 374047 \\
\hline & By uses & Housing & 40328 & 94392 & 20000 & 48000 & 60855 & 12775 & 276349 \\
\hline & & $\begin{array}{l}\text { Trade and/or } \\
\text { services }\end{array}$ & 4275 & 32067 & 0 & 5370 & 6000 & 0 & 47712 \\
\hline & & Tourism & 19100 & 15150 & 2436 & 7000 & 6300 & 0 & 49986 \\
\hline \multirow{4}{*}{$\begin{array}{l}\text { Net use index }\left(\mathrm{m}^{2} \text { of gross built area } / \mathrm{m}^{2} \text { of plot }\right. \\
\text { area) }[3]=[2] /[1]\end{array}$} & TOTAL & & 2.20 & 2.53 & 0.59 & 3.06 & 3.06 & 0.28 & 1.77 \\
\hline & By uses & Housing & 1.40 & 1.68 & 0.53 & 2.44 & 2.55 & 0.28 & 1.31 \\
\hline & & $\begin{array}{l}\text { Trade and/or } \\
\text { services }\end{array}$ & 0.15 & 0.57 & 0.00 & 0.27 & 0.25 & 0.00 & 0.23 \\
\hline & & Tourism & 0.66 & 0.27 & 0.06 & 0.36 & 0.26 & 0.00 & 0.24 \\
\hline \multirow{4}{*}{$\begin{array}{l}\text { Difference in relation to the average built area/ } \\
\mathrm{m}^{2}[4]=[3]-0.1716\end{array}$} & TOTAL & & 2.03 & 2.35 & 0.42 & 2.89 & 2.89 & 0.11 & 1.60 \\
\hline & By uses & Housing & 1.22 & 1.51 & 0.35 & 2.26 & 2.38 & 0.11 & 1.14 \\
\hline & & $\begin{array}{l}\text { Trade and/or } \\
\text { services }\end{array}$ & -0.02 & 0.40 & -0.17 & 0.10 & 0.08 & -0.17 & 0.05 \\
\hline & & Tourism & 0.49 & 0.10 & -0.11 & 0.18 & 0.09 & -0.17 & 0.06 \\
\hline \multirow{4}{*}{$\begin{array}{l}\text { Minimum betterment values, considering the } \\
\text { minimum average annual land market price/ } \\
\mathrm{m}^{2}(€)[5]=[2] \times[4] \times 95\end{array}$} & TOTAL & & 5565596 & 14919082 & 647191 & 10496036 & 13841221 & 137343 & 30350643 \\
\hline & By uses & Housing & 4687605 & 13557648 & 672096 & $10 \quad 322527$ & $13 \quad 740 \quad 624$ & 137343 & 29798465 \\
\hline & & $\begin{array}{l}\text { Trade and/or } \\
\text { services }\end{array}$ & -9626 & 1219514 & 0 & 51449 & 45404 & 0 & 244723 \\
\hline & & Tourism & 887617 & 141920 & -24904 & 122061 & 55193 & 0 & 307454 \\
\hline \multirow{4}{*}{$\begin{array}{l}\text { Maximum betterment values, considering the } \\
\text { maximum average land market price } / \mathrm{m}^{2}(€) \\
{[6]=[2] \times[4] \times 265}\end{array}$} & TOTAL & & 15525084 & 41616387 & 1805324 & 29278417 & 38609722 & 383115 & 84662320 \\
\hline & By uses & Housing & 13075952 & 37818702 & 1874793 & 28794417 & 38329109 & 383115 & 83122035 \\
\hline & & $\begin{array}{l}\text { Trade and/or } \\
\text { services }\end{array}$ & -26852 & 3401803 & 0 & 143515 & 126653 & 0 & 682649 \\
\hline & & Tourism & 2475984 & 395881 & -69469 & 340485 & 153960 & 0 & 857636 \\
\hline \multirow{4}{*}{$\begin{array}{l}20 \% \text { of the minimum betterment values }(€) \text { [7] } \\
\quad=0.2 \times[5]\end{array}$} & TOTAL & & 1113119 & 2983816 & 129438 & 2099207 & 2768244 & $27 \quad 469$ & 6070129 \\
\hline & By uses & Housing & 937521 & 2711530 & 134419 & 2064505 & 2748125 & 27469 & 5959693 \\
\hline & & $\begin{array}{l}\text { Trade and/or } \\
\text { services }\end{array}$ & -1925 & 243903 & 0 & 10290 & 9081 & 0 & 48945 \\
\hline & & Tourism & 177523 & 28384 & -4981 & 24412 & 11039 & 0 & 61491 \\
\hline \multirow{4}{*}{$\begin{array}{l}20 \% \text { of the maximum betterment values }(€)[8] \\
\quad=0.2 \times[6]\end{array}$} & TOTAL & & 3105017 & 8323277 & 361065 & 5855683 & 7721944 & 76623 & 16932464 \\
\hline & By uses & Housing & 2615190 & 7563740 & 374959 & 5758883 & 7665822 & 76623 & 16624407 \\
\hline & & $\begin{array}{l}\text { Trade and/or } \\
\text { services }\end{array}$ & -5370 & 680361 & 0 & 28703 & 25331 & 0 & 136530 \\
\hline & & Tourism & 495197 & 79176 & -13894 & 68097 & 30792 & 0 & 171527 \\
\hline
\end{tabular}

transactions varies between 95 and $265 € / \mathrm{m}^{2}$ of land.

The betterment values are approached through the product of the difference between the land occupation capacity $/ \mathrm{m}^{2}$ licensed in a certain urban development operation and the average municipal building capacity $/ \mathrm{m}^{2}$, the land market price $/ \mathrm{m}^{2}$, and the maximum licensed gross built surface for the studied intervention, summed up to all their plots, for all the anticipated uses. The following methodology was pursued in this computation:

- Determination of the net occupation index per $\mathrm{m}^{2}$ of each urban development unit [3], through the quotient between the gross built surface for profitable uses ${ }^{6}$ [2] and the land plot areas [1];

- Computation of the difference [4] between the net occupation index $/ \mathrm{m}^{2}$ of each urban development unit for each kind of use [3] and the municipal average built surface $/ \mathrm{m}^{2}\left(0.1716 \mathrm{~m}^{2}\right.$ of gross built surface $/ \mathrm{m}^{2}$ of land in the whole developed and developable municipal urban surface);

- The minimum betterment value considering the minimum land market price $/ \mathrm{m}^{2}[5]$, is assessed through the product between the value of the difference in relation to the municipal average built surface $/ \mathrm{m}^{2}$ [4], the minimum land market price $/ \mathrm{m}^{2}\left(95 € / \mathrm{m}^{2}\right)$, and the maximum licensed gross built surface [2];

- The maximum betterment value considering the maximum land market price $/ \mathrm{m}^{2}[6]$, is assessed through the product between the

\footnotetext{
${ }^{6}$ Profitable uses include housing, trade, services and tourism.
}

value of the difference in relation to the municipal average built surface $/ \mathrm{m}^{2}$ [4], the maximum land price $/ \mathrm{m}^{2}$ based on market trade $\left(265 € / \mathrm{m}^{2}\right)$, and the maximum licensed gross built surface [2];

- Finally, the potential taxable value that accrues from the application of this new developers' obrigation instrument represents $20 \%$ of the amounts of these minimum [7] and maximum [8] betterment values (Table 6).

The presented reasoning, considering the range of land average annual market price $/ \mathrm{m}^{2}$ in the municipality of Ourém, leads to the conclusion that the betterment value that accrues from the assignment of a building right higher than the municipal average built area $/ \mathrm{m}^{2}$ to the urban development intervention covered by the current Detail Plan, varies between 30350643 and 84662320 euros. Herein is proposed that the municipality should collect $20 \%$ of this value, which ranges between 6070129 and 16932464 euros.

Considering that the multiannual municipal investment plans last four years, and that those values will reflect troughout 20 years, their weight in the multiannual investment plans of the municipality vary between $0,9 \%$ and $1,6 \%$ in the worse scenario, and between $2,4 \%$ and $4,4 \%$ in the most favourablescenario (Table 7).

The betterment thus collected can be applied to many different municipal goals, namely to cover part of the construction, enlargement or maintenance costs of infrastructure, or to cover part of costs with social housing or other social concerns.

The rubrics of the municipal Options' Plan and of the multiannual investment plan eligible for additional funding are the social action, 
Table 7

Percentage weight of minimum and maximum levies on multiannual investments plans of the municipality of Ourém in 2009, 2010, 2011 and 2012.

\begin{tabular}{lllll}
\hline & 2009 & 2010 & 2011 & 2012 \\
\hline $\begin{array}{c}\text { Multiannual investment } \\
\text { plans (€) }\end{array}$ & 139017443 & 77453001 & 79010483 & 76956940 \\
$\begin{array}{c}\text { Minimum levy (6 070 } \\
\quad 129 € \text { ) } \\
\text { Maximum levy (16 932 }\end{array}$ & $0.9 \%$ & $1.6 \%$ & $1.5 \%$ & $1.6 \%$ \\
$464 €)$ & $2.4 \%$ & $4.4 \%$ & $4.3 \%$ & $4.4 \%$ \\
\hline
\end{tabular}

housing and urban development, sanitation and healthfulness, civil protection and environment preservation.

Multiannual investment plans present the expected expenses for a four-year term (beginning in the reported one). Municipal Options' Plans present the desirable investments settled by decision-makers that should be pursued, despite requiring additional funding. They also refer to homologous four-year periods.

The corresponding values both for the former and for the latter for 2009, 2010, 2011 and 2012 are as follows (Table 8):

The "desirable" investments in these fields are higer in relation to total investments than the predicted ones.

The executed level of pursued investments in relation to "desirable" ones vary between $38.5 \%$ and $55 \%$ in the studied years (Table 9).

Considering that the betterments levied through the proposed instrument will reflect on municipal accounts for a twenty-year period, the predicted charges for the four-year periods will be increased, on average, by one fifth of those values. The upper and lower limits of the percentual execution of "desirable investments" will, thus, increase between $3 \%$ and $6 \%$ for the former, and between $1,1 \%$ and $2.1 \%$ for the latter.

So a useful method to evaluate the contribution of the income levied through the proposed instrument on planned investments and on the execution levels of "desirable planning" may found, namely, on the development of an ongoing urban management system. The efficiency indicator should, thus, consist in summing the levied incomes of each urban operation ruled by plans to budgeted values (for corresponding periods), and make percentual comparisons against the values settled in the Options Plan. Based on the values of this indicator, municipal decision-makers could afterwards decide on the application of levies (in each of the identified kinds of investments), and spread this information throughout the whole population.

However, considering the fact that social action only represents around $1 \%$ of investments, and that there are other straight or indirect taxes that support the other kinds of investments (particularly in infrastructure, which is the most representative amongst investments), the application of the levied amounts to social goals would not only cover their charges, but could also trigger additional initiatives in this field.

\section{Discussion}

This article reports the design and application of a non-negotiable developer obligation aimed at recovering a part of land betterments engendered by plan's approval and implementation. It specifically
Table 9

Percentage that investments in social action, housing and urban development, sanitation and healthfulness, civil protection and environment preservation predicted in annual investment plans represent in relation to Options' Plans and respective variations, considering the contribution to effective investments of the collected levies in 2009, 2010 2011 and 2012.

\begin{tabular}{lllll}
\hline & 2009 & 2010 & 2011 & 2012 \\
\hline Effective charges/Desirable charges & $55.0 \%$ & $42.0 \%$ & $30.9 \%$ & $38.4 \%$ \\
Execution of desirable charges (upper limit) & $58.0 \%$ & $47.7 \%$ & $36.9 \%$ & $43.8 \%$ \\
Execution of desirable charges (lower limit) & $56.1 \%$ & $44.1 \%$ & $33.1 \%$ & $40.3 \%$ \\
Variation (upper limit) & $3.0 \%$ & $5.7 \%$ & $6.0 \%$ & $5.4 \%$ \\
Variation (lower limit) & $1.1 \%$ & $2.0 \%$ & $2.1 \%$ & $1.9 \%$ \\
\hline
\end{tabular}

focuses on the taxation of licensed built areas above the municipal average building potential $/ \mathrm{m}^{2}$. It was extensively applied, as a case study, to the Detail Plan of Avenue Pope John XXIII, in Fátima (in the Municipality of Ourém, Portugal).

It expresses the concern to provide municipalities with instruments that complement tradicional funding sources, considering the current crisis framework (that strongly shapes municipal finance). This proposal founds on the awareness that increases in land values engendered by planning decisions should revert on behalf of the population. This is accomplished though a methodology to assess betterment values in territorial plans.

This proposal was developed as a consultancy work and research developed for the Portuguese Territory Department (that belongs to the government) within the scope and spirit of the revision of the land and planning legislation. It is intended to be included in new territorial and urban development plans. It fits the goal settled in the Land and Planning Act to ensure the economic and financial feasibility of land use and changes. This instrument is near the citizens (at municipal level), is easily operationable, and is advantageous from different perspectives, assessed as follows.

It seems to be a fair instrument. Because, at first, its application will focus on development operations resulting from plans approved. It means that it doesn't contemplate negotiated tradeoffs settled outside plans concerning the levy of promoters as a setback for the assigment of additional building rights, zoning, or slackness in existing land use regulations. Secondly, its objective computation methodology and the equalisation mechanisms it settles among promoters and among municipalities enable control over speculation in property prices. Thirdly, because it represents an income for the municipality: it is like a tax but it doesn't levy general citizens. It only focuses on urban developers, and even those are only levied on $20 \%$ of the expected betterment. So it doesn't stop the private initiative, and recovers a part of the betterment introduced by plans and other urban licenses. Fourthly, because the levies collected through this instrument may nourish a sustainability fund, which may be used to complement infrastructure and public equipment funding, as well as other municipal social charges. It can further stimulate municipalities to engage in additional social concerns, because usually incomes are guided to other uses that convey higher visibility. Additionaly, because it settles equalisation mechanisms among promoters and municipalities, through the adoption of average municipal values as a benchmark, through the application of the municipal real estate tax code, and through the use of statistical data from

Table 8

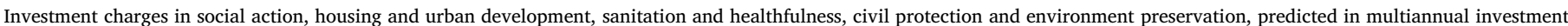
plans and Options' plans of the municipality of Ourém in 2009, 2010, 2011 and 2012.

\begin{tabular}{|c|c|c|c|c|c|c|c|c|}
\hline \multirow[b]{2}{*}{ Eligible multiannual investment charges } & \multicolumn{2}{|l|}{2009} & \multicolumn{2}{|l|}{2010} & \multicolumn{2}{|l|}{2011} & \multicolumn{2}{|l|}{2012} \\
\hline & 62586073 & $45.0 \%$ & 24918256 & $32.2 \%$ & 17481818 & $22.1 \%$ & 24111284 & $31.3 \%$ \\
\hline Total municipal multiannual investment charges & 139017443 & $100.0 \%$ & 77453001 & $100.0 \%$ & 79010483 & $100.0 \%$ & 76956940 & $100.0 \%$ \\
\hline Eligible Options' Plans charges & 113725284 & $51.3 \%$ & 59305521 & $41.5 \%$ & 56564040 & $36.4 \%$ & 62844499 & $43.2 \%$ \\
\hline Total municipal Options' Plans charges & 221588872 & $100.0 \%$ & 142894897 & $100.0 \%$ & 155291945 & $100.0 \%$ & 145415537 & $100.0 \%$ \\
\hline
\end{tabular}


certified and trustworthy sources. And, finally, because it respects municipal identities, as the consideration of average municipal built areas as a benchmark, besides balancing the treatment of developers, further preserves their endogenous and historical and cultural characteristics, projecting them forward. This instrument is near the concrete territorial realities, comes along with municipal development, and results from the experience with the application of urban plans, trying to surmount many shortcomings and troubles that emerged in their application.

This developers' obligation instrument is also more effective than already existent ones, even in other countries, for many reasons. First for technical reasons, because it clearly assesses land values and betterment, resorting to the urban parameters objectively settled in plans and licenses. It conveys a better awareness of the existence of pressure groups and interests, and doesn't consider any yielding to these groups through assignment of fine-tuned specific licenses. It is only applied to urban operations settled in plans through objective parameters. Secondly, because as already argued, it fits the concerns of the recently approved Land and Planning Act, especially in what concerns the requirement to introduce in plans methodologies to assess the economic and financial sustainability of urban development interventions. Thirdly, because the proposal to clearly inform citizens about the foreseen application of levied incomes will probably rise up their support for this instrument, together with the awareness that this isn't a tax so common citizens won't be levied as such. Forthly, its operationalization is easy because, at least in Portugal, the land assessment system is very developed, based on a plot-by-plot based evaluation system, regularly updated, and upon which the municipal real estate code is applied. This assessment is in charge of each municipality (decentralised), and applied by experts, what strengthens the management ability to implement it. Both these issues convey a better knowledge of public decision-makers on the maturity of markets. It is important, however, to duly explain the assumptions, methodology and potentialities of this new instrument to polititians and to promoters, in order to gather their support, and promote the diffusion of good practices in their implementation to the whole territory.

\section{Conclusions}

The developer obligations instrument herein reported - that consists in the capture of part of betterment that accrue from planning decisions - presents many advantages for municipalities

- It helps to surmount public funding shortcomings, as it provides additional funds for public services, infrastructure, equipment, affordable housing, and other social concerns

- It transfers to developers the obligation to support part of urban development charges, against the grant of building rights above the average municipal level, not overburdening citizens with taxes

- It clears the origins of funds that accrue from urban development, objectively quantifies their concrete obtainable contributions, and suggests that municipalities should inform citizens on the concrete applications of these levies

- It doesńt discourage the private initiative of landowners and developers because it proposes the collection of only a part of betterment

- It tends to lower land prices and to control speculation, and is economically efficient. Indeed, considering the inelasticity of land supply in certain locations and more harsh legislation on land use (to which this instrument contributes), the burden either with infrastructure or with social engagements will fall on landowners and developers that, by their turn, won't possess anymore the legal and economic means to transfer it to the final users

- The proposed distribution of benefits and charges that accrue from urban development processes is equitable because it takes as benchmark the municipal average building capacity
- It assures that betterment values that accrue from urban operations and from municipal planning decisions or public investments are allocated on behalf of the population's general interest and not for private-oriented specific interests (it is proposed that the collected values nourish a fund assigned to urban infrastructure and equipment, social housing and other social goals)

- It resorts to available, reliable, comparable and universal data, ensuring the assessment of betterments and of corresponding predicted levies based on clear and objective parameters (of concrete and average municipal gross built areas $/ \mathrm{m}^{2}$ ), and is easily computable

- It develops a tax or contribution that won't fall upon citizens who, additionally, will become more aware both of betterment origins and on their concrete applications on behalf of the overall community (as they will be duly informed on the application of collected levies)

Conditions for success, from an operational perspective, are also achievable through the current proposal:

- In what concerns legal issues, it fits the recently approved Portuguese legislation on land, territorial planning and urban development, observing land property rights

- A concrete methodology to approach and compute betterment values is presented - within the framework of different land value capture alternative systems in operation in different countries that founds on a reliable land assessment (in terms of data and real estate tax code). It is supposed that the current structures for tax collection at the municipal level may be applied to manage land

- It is suggested the development of a management information system to store and retrieve updated information, and the use of communication technologies in order to increase the computational efficiency of this territorial management instruments (in the framework of all other instruments).

- Besides, the use of comparable, reliable and universal statistical data assures impartiality towards different stakeholders and local land markets

- It is also proposed the development of an ongoing indicator that relates the incomes levied through this instrument and the investments defined both in multiannual investment budgests and in Options' Plans.

- Its computation steps are clear and may be easily explained to politicians and developers, as an operational supplement to the new planning rules and procedures

- This methodology clears up the amounts of funding coming from each urban development operation within a certain municipality. It further provides the basis for municipal decisions concerning the predicted application of the funds thus obtained.

- Finally, it is intended that this proposal should be sufficiently diffused so that citizens become aware of the application of levied incomes.

This methodology can as well be extended to other municipalities and intervention areas of Municipal Master Plans, Urban Development Plans or Detail Plans, as they ground on feasible and comparable available data. This will clearly point out the concrete possible ranges of taxable values, which will afterwards support municipal decisions concerning investments in infrastructure, equipment or general or specific social goals.

This new territorial management instrument shall be integrated with other territorial policies, fitting the concerns that master the current revision of the Portuguese Land and Planning Act, the juridical regimes of Territorial Management Instruments and of Urbanization and Edification, the new Cadastral Law, and the new generation of territorial plans and respective regulatory precepts. It indeed contributes to a new territorial paradigm, through the simplification of plans' design and implementation, clarification of concepts, rules, and 
methodologies, and control over land prices and speculation

Despite general legislation may include this territorial management instrument (or other similar value capture instruments) that settles basic standardised principles, some discretionary powers should, conversely, be left for municipal decision-makers. This subjective room for manoeuvre contemplates the specific characteristics and realities of each municipality, and takes inter-municipal complementarities and incompatibilities into consideration.

The adoption and implementation of this kind of value capture instruments presupposes the dissemination of its spirit, underlying goals and methodology throughout the municipal technicians, in particular, and the whole population, in general. It specifically requires technical education and training, and the empowerment of municipal technicians, strengthening their awareness, sensitiveness and knowledge of these policies and instruments in order to better apply them.

It is also relevant that computer routines and cartographic digital interfaces based on the proposed methodology are developed and provided to these technicians, thus fostering the implementation of an integrated and interactive decision support system, triggering colaborative networks, and the interchange of information and experiences. This would certainly represent a step forward in the efficiency of the new land planning and management, territorial ordering and urban development paradigm that the overall new territorial policy wants to pursue!

\section{Acknowledgements}

The author thanks the Portuguese Territory Department (Direção Geral do Território) for all the given support.

\section{References}

Alexander, G., Penalver, E.M., Singer, J.W., Underkuffl, L.C., 2009. A statement of progressive property. Cornell Law Rev. 94 (4), 743-744.

Alterman, R., 1982. Land Value Recapture: Design and Evaluation of Alternative Policies. Occasional Paper $n^{\circ}$ 26. Centre for Human Settlements, University of British Columbia.

Alterman, R., 1988. Exactions american style: the context for evaluation. In: Alterman, R. (Ed.), Private Supply of Public Services: Evaluation of Real-Estate Exactions, Linkage and Alternative Land Policies. NYU Press, New York.

Alterman, R., 2010. Takings International: A Comparative Perspective on Land Use Regulations and Compensation Rights. American Bar Association Publications, Chicago.

Alterman, R., 2011. Is capturing the unearned increment in land value still a viable idea? A cross-national analysis. COBRA 2011-Proceedings of RICS Construction and Property Conference 1233-1252.

Alterman, R., 2012. Land use regulations and property values: the windfalls capture idea revisited. In: Brooks, K.D., Knaap, G.-J. (Eds.), The Oxford Handbook of Urban Economics and Planning. Oxford University Press, Oxford, pp. 755-786.

Altshuler, A.A., Gomez-Ibanez, J.A., 1993. Regulation for Revenue: The Political Economy of Land Use Exactions. Brookings Institution Press, Washington, DC.

Atmer, T., 1987. Land banking in Stockholm. J. Am. Plann. Assoc. 47 (3), 279-288.

Ayougu, M., 2007. Infrastructure and economic development in Africa: a review. J. Afr. Econ. 16 (1), 75-126.

Bhatta, S.D., Drennan, M.P., 2003. The economic benefits of public investment in transportation - A review of recent literature. J. Plann. Educ. Res. 22 (3), 288-296.

Barker, K., 2004. Review of Housing Supply: Final Report - recommendations Crown Copyright for Deputy Prime Minister. . http://www.barkerreview.org.uk.

Barrett, S., Boddy, M., Stewart, M., 1979. Implementation of the Community Land Scheme. School of Advanced Studies. Occasional Paper $n^{\circ}$ 3. University of Bristol.

Booth, P.A., 2003. Planning by Consent: The Origins and Nature of British Development Control. Routledge, New York.

Booth, P.A., 2012. The unearned increment: property and the capture of betterment value in Britain and France. In: Ingram, G.K., Hong, Y.-H. (Eds.), Value Capture and Land Policies. Lincoln Institute of Land Policy, Cambridge, MA.

Bourassa, S.C., Hong, Y.-H., 2003. Leasing Public Land. Lincoln Institute of Land Policy, Cambridge, MA.

Brown, H.J., Smolka, M.O., 1997. Capturing public value from public investments. In: Brown, H.J. (Ed.), Land Use and Taxation: Applying the Insights of Henry George. Lincoln Institute of Land Policy, Cambridge, MA.

Calavita, N., Clusa, J., Mur, S., Weiner, R., 2010. Spain's constitutional mandates: the right to housing, land value recapture, and inclusionary housing. In: Calavita, N., Mallach, A. (Eds.), Inclusionary Housing in International Perspective: Affordable Housing Social Inclusion and Land Value Recapture. Lincoln Institute of Land Policy, Cambridge, MA, pp. 239-274.

Calavita, N., Mallach, A., 2009. Inclusionary housing, incentive and land value recapture.
Land Lines 21, 15-21.

Carroll, D.A., 2008. Tax increment financing and property value. Urban Affairs Rev. 43 (4), 520-552.

Callies, D.L., Suarez, A., 2005. The law and politics of local governance: privatization and the providing of public facilities through private means. J. Law Politics 21, 477-504.

Canning, D., Pedroni, P., 2008. Infrastructure, long-run economic growth and causality tests for co-integrated panels. Manchester School 76 (5), 504-527.

Capalbo, A., 2006. Gli strumenti di pianificazione urbanistica. In: Dal Programma Di Fabbricazione Al Piano Strutturale. Halley.

Cardoso, I.M., Almeida, L.M., Vilares, E., Ferreira, F., 2011. Análise Comparativa Das Leis Dos Solos De Países Europeus-Estudo De Enquadramento Para a Preparação Da Nova Lei Do Solo, Documento Técnico DGOTDU 8/2011. Ministério do Ambiente e do Ordenamento do Território, Direcção Geral do Ordenamento do Território e Desenvolvimento Urbano, Portugal.

Correia, P.V.D., Lobo, I.M.C., Sousa, R.M.C., Costa, P., Alves, R.A., George, P., Alves, F.B., Vale, D., Costa, P., Zangui, M., Séves, A.L., Duarte, I., 2001. Relatório do plano de urbanização de Fátima. Câmara Municipal de Ourém, Portugal.

Correia, P.V.D., Corvêlo, R.M., Lobo, I.M.C., Alves, R.A., Alves, F.B., Oliveira, V. Monteiro, F., Sèves, A.L., Matos, I.A., Costa, P., Martins, P., Duarte, I., 2002. Relatório Do Plano Director Municipal De Ourém, Proposta Final, vol. 1 Câmara Municipal de Ourém, Portugal.

Crook, T., Currie, J., Jackson, A., Monk, S., Rowley, S., Smith, K., Whitehead, C., 2012. Planning Gain and Affordable Housing: Making It Count. Joseph Rowntree Foundation, York, UK.

DGOTDU, 2011. Preparação do projecto da nova Lei do Solo: Workshop com Especialistas. Documento de apoio ao debate. Direcção Geral do Ordenamento do Território e Desenvolvimento Urbano, Lisboa, Portugal.

Daniels, T.L., Daniels, R.H., Lapping, M.B., 1986. The Vermont land gains tax: experience with it provides a useful lesson in the design of modern land policy. Am. J. Econ. Sociol. 45 (4), 441-455.

Davy, B., 2007. Mandatory happiness? Land readjustment and property in Germany. In: Needham, B., Hong, Y.-H. (Eds.), International Experiences in Land Readjustment. Lincoln Institute of Land Policy, Cambridge, MA, pp. 37-56.

Denyer-Green, B., 1998. Compulsory Purchase and Compensation, 5th ed. Estates Gazette, London.

Land Readjustment: A Different Approach to Financing Urbanization. In: Doebele, W.A. (Ed.), Lexington Books, Lexington, MA.

England, R.D., 2007. Land value taxation as a method of financing municipal expenditures in US cities. In: Ingram, G.K., Hong, Y.-H. (Eds.), Land Policies and Their Outcomes. Lincoln Institute of Land Policy, Cambridge MA, pp. 185-200.

Feinstein, S., 2012. Land value capture and justice. In: Ingram, G.K., Hong, Y.-H. (Eds.), Value Capture and Land Policies. Lincoln Institute of Land Policy, Cambridge, Massachussets, pp. 21-40.

Furtado, F., Bacellar, I., 2016. Public charge and private transfer of building rights in Brazil: the need for coherence in regulation and implementation. In: IV World Planning Schools Congress. Rio de Janeiro, July 3rd-8th..

George, H., 1962. Progress and Poverty. Robert Shalkenbach Foundation, New York.

Gielen, D.M., 2008. Public value capturing and the financing of public infrastructure in England, Valencia and The Netherlands. In: Paper Presented at the Conference of the International Academic Group on Planning Law and Property Rights. Warsaw, February.

Gielen, D.M., Krabben, E., Alterman, R., 2015. In: 10th Annual Conference International Academic Association on Planning, Law and Property Rights, Special Session on Developer Obligations. Bern, Switzerland, 17th-19th February. http://www.geography.unibe.ch/content/forschungsgruppen/raumentwicklung_und_planung/ plpr 2016 conference/index eng.html (retrieved August 2016).

Gihring, T.A., 1999. Incentive property taxation: a potential tool for urban growth management. J. Am. Plann. Assoc. 65 (1), 62-79.

Grant, M., 1999. Compensation and betterment. In: Cullingworth, B. (Ed.), British Planning. Athlone Press, London, pp. 62-76.

Hong, Y.-H., Brubaker, D., 2010. Integrating the proposed property tax with the public leasehold system. In: Man, J.Y., Hong, Y.-H. (Eds.), China's Local Public Finance in Transition. Lincoln Institute of Land Policy, Cambridge, MA.

Hall, P., 1976. A review of policy alternatives. In: Kehoe, D. (Ed.), Public Landownership: Framework for Evaluation. Lexington Books, Toronto, pp. 46-57.

Haughwout, A.F., 2002. Public infrastructure investments, productivity, and welfare in fixed geographic areas. J. Public Econ. 83, 405-428.

Hendricks, M., Tonkin, A., 2010. Land Value Capture/taxation (LVC/T) Scoping Study. Final report Development Action Group, Cape Town, South Africa.

Hui, E.C.-M., Ho, V.S.-M., Ho, D.K.-H., 2004. Land value capture mechanisms in Hong Kong and Singapore. J. Property Invest. Finance 22 (1), 76-100.

Hong, Y., 1998. Transaction Costs of allocating increased land value under public leasehold systems: Hong Kong. Urban Stud. 35 (9), 1577-1595.

Ingram, G.K., Hong, Y.-H., 2007. Land Policies and Their Outcomes. Lincoln Institute of Land Policy, Cambridge, MA.

Ingram, G.K., Hong, Y.-H. (Eds.), 2012. Value Capture and Land Policies. Puritan Press Inc., Lincoln Institute of Land Policy, Cambridge, Massachusetts, New Hampshire.

INE, 2009. Anuário Estatístico Da Região Centro 2008. Instituto Nacional de Estatística, I. P., Lisboa, Portugal. http://www.ine.pt.

INE, 2010. Anuário Estatístico Da Região Centro 2009. Instituto Nacional de Estatística, I. P., Lisboa, Portugal. http://www.ine.pt.

INE, 2011a. Censos 2011. Instituto Nacional de Estatística, Lisboa, Portugal. http:/ censos.ine.pt/xportal/xmain?xpid = CENSOS\&xpgid = censos2011_apresentacao.

INE, 2011b. Anuário Estatístico Da Região Centro 2010. Instituto Nacional de Estatística, Lisboa, Portugal. http://www.ine.pt.

INE, 2012. Anuário Estatístico Da Região Centro 2011. Instituto Nacional de Estatística, 
Lisboa, Portugal. http://www.ine.pt.

Ko, K., Rosenblatt, B., 2013. Land Value Capture 101: How to Fund Infrastructure with Increased Property Values. http://blog.tstc.org/2013/08/19/land-value-capture101-how-to-fund-infrastructure-with-increased-property-values.

Laanly, C., Renard, V., 1990. Public land banking. In: Renard, V., Comby, J. (Eds.), Land Policy in France. EDEF, Paris, pp. 47-56.

Lam, A.H.S., Tsui, S.W.-C., 1998. Policies and Mechanisms on Land Value Capture: Taiwan Case Study. Lincoln Institute of Land Policy, Cambridge, MA.

Lefebvre, H., 1991. The Production of Space (Trans. D. Nicholson-Smith). Blackwell, Oxford, U.K.

Lichfield, N., Darin-Drabkin, H., 1980. Land Policy in Planning. George Allen and Unwin, London.

Lopes, E., Reis, P., Oliveira, A.P., Oliveira, F.P., Ferreira, J., Lopes, J., Vaz, S., 2014. Plano De Urbanização De Fátima-Alteração. Município de Ourém, Câmara Municipal, Divisão de Planeamento e Ordenamento do Território, Portugal.

McAuslan, P., 1980. The Ideologies of Planning Law. Pergamon Press Oxford.

Mazza, M.G., 2005. Il Trasferimento Della Capacità Edificatoria. Disciplina, effetti ed opportunità pubbliche e private, Halley.

Mikelbank, B.A., 2004. Spatial analysis of the relationship between housing values and investments in transportation infrastructure. Ann. Reg. Sci. 38 (4), 705-726.

Ministère de l'Aménagement du Territoire, 2017. De La Ruralité Et Des Collectivités Territoriales. Ministère de l'Aménagement du Territoire. http://www.territoires. gouv.fr/droit-de-l-urbanisme.

Morelli, M., 2007. La Planificazione urbanística. Dal piano regolatore generale ai piani attuativi. Halley.

Moreno, R., Lopez-Bazo, E., 2007. Returns to local and transport infrastructure under regional spillovers. Int. Reg. Sci. Rev. 30 (1), 47-71.

Murphy, R., 2013. It'sTime to Increase the Tax on Unearned Income. Itts so Glaringly Obviously True Why Will No One Say It? http://www.taxresearch.org.uk/Blog/ 2013/01/22/its-time-to-increase-the-tax-on-unearned-income-its-so-glaringlyobviously-true-why-will-no-one-say-it/.

Needham, B., Hong, Y.-H., 2007. International Experiences in Land Readjustment. Lincoln Institute of Land Policy, Cambridge, MA.

Nelson, A., Bowles, L., Juergensmeyer, J., Nicholas, J., 2008. A Guide to Impact Fees and Housing Affordability. Island Press, Washington, DC.

Netzer, D., 1998. Land Value Taxation: Could It Work Today?. Land Lines 10. http:// www.lincolninst.edu/pubs/426_Land-Value-Taxation?-Could-It-Work-Today.

Peterson, G.E., 2009. Unlocking Land Values to Finance Urban Infrastructure. Trends and Policy Options Series, $n^{\circ}$ 7. The International Bank for Reconstruction and Development/The World Bank, Washington, DC.

Rebelo, E.M., 2009. Land economic rent computation for urban planning and fiscal purposes. Land Use Policy 26 (3), 521-534.

Rebelo, E.M., 2012. Planning to fight speculation: outstanding influences on land rent Chapter 4. In: Lee, T.H. (Ed.), Agricultural Economics: New Research. Nova Science Publishers, pp. 89-111.

Rebelo, E.M., 2014a. Contributos para o regime económico-financeiro do solo e ordenamento do território. Estudo De Caso Do Plano De Pormenor Da Avenida Papa João XXIII (Fátima).

Rebelo, E.M., 2014b. Municipal finance sustainability: a new territorial management instrument to redistribute surplus-values accrued by plans. Renaissance of the Regions of Southern Europe-Atas/Proceedings 20th APDR Congress 1432-1441.

Rebelo, E.M., 2014c. Social assignment of surplus-values accrued by plans: a new sustainable urban management instrument. In: CITTA 7th Annual Conference on Planning Research, Bridging the Implementation Gap of Accessibility Instruments and Planning Support Systems. Faculdade de Engenharia (U. P.), Portugal.

Rebelo, E.M., 2014d. Sustainable urban planning from an economic and financial perspective. In: 40th IAHS World Congress on Housing Sustainable Housing Construction. Funchal, Portugal, 13st-16th December.

Rebelo, E.M., 2014e. Municipal average building capacity: a strategic instrument for economic and financial sustainability of urban developments. In: ISUF 21st International Seminar on Urban Form. Porto, Portugal, 3rd-6th July..

Rebelo, E.M., 2014f. Contributos para o regime económico-financeiro do solo e ordenamento do território. In: Estudo De Caso Do Plano De Urbanização Da Unidade De Planeamento 11. (Lagoa, Algarve)

Rebelo, E.M., 2014g. Sustainable urban planning from an economic and financial perspective. In: 40th IAHS World Congress on Housing Sustainable Housing Construction. Funchal, Madeira, December.

Rosenberg, R.H., 2006. The Changing Culture of American Land Use Regulation: Paying for Growth with Impact Fees. Southern Methodist University Law Review, Winter.

Skaburskis, A., Qadeer, M., 1992. An empirical estimation of the price effects of development impact fees. Urban Studies 29 (5), 653-667.

Siethoff, B., Kockelman, K.M., 2002. Property values and highway expansion: timing, size location, and use effects. Trans. Res. Rec. Ed. 1812, 191-200.

Smith, J.J., Gihring, T.A., 2006. Financing transit systems through value capture. Am. J. Econ. Sociol. 65 (3), 751-786.

Smolka, M., Amborski, D., 2003. Recuperación de plusvalías para el desarrollo urbano: una comparación inter-americana. EURE - Revista Latino Americana de Estudios Urbano Regionales 29 (88), 55-77.

Smolka, M.O., Amborski, D., 2007. Value Capture for Urban Development: An InterAmerican Comparison. Working Paper. Lincoln Institute of Land Policy. http:// lincolnint.edu/pubs/download.asp?doc_id = 576\&pub_id $=1279$.

Smolka, M.O., Furtado, F., 2001. Lessons from Latin American experience with value capture. Land Lines 13 (4). http://www.lincolnint.edu/pubs/233_Lessons-from-theLatin-America-Experience-with-Value-Capture.

Smolka, M.O., Furtado, F., 2003. The value capture debate in Latin America. Land Lines 15 (3). http://www.lincolnint.edu/pubs/832_The-Value-Capture-Debate-in-LatinAmerica.

Strong, A.L., 1979. Land Banking. John Hopkins University Press, Baltimore.

Taylor, L.L., Brown, S.P.A., 2006. The private sector impact of state and local government: has more become bad? Contemp. Econ. Policy 24 (4), 548-562.

Terraforma, José Lamas e Associados, 2009. Sociedade de estudos e projectos, 1da., José Lamas e associados, estudos de planeamento e arquitectura, lda. In: Relatório Do Plano De Pormenor Da Avenida Papa João XXIII. Câmara Municipal de Ourém, Portugal.

Tichelar, M., 2003. The conflict over property rights during the second world war. Twentieth Cent. Br. Hist. 14 (2), 165-188.

United Nations, 1976. The Vancouver action plan - Recommendation D.3. In: United Nations Conference on Human Settlements. Vancouver, Canada.

Walters, L.C., 2011. Land and Propery Tax: A Policy Guide. UN_Habitat and the Global Land Tool Network, Nairobi, Kenya.

Walters, L.C., 2012a. To what extent are property related taxes effective value capture instruments? In: Ingram, G.K., Hong, Y.-H. (Eds.), Value Capture and Land Policies. Lincoln Institute of Land Policy, Cambridge, MA.

Walters, L., 2012b. Land value capture in policy and practice. In: World Bank Conference on Land and Poverty. Brigham Young University Washington, DC..

Webb, M.S., 2013. How a Levy Based on Location Values Could Be the Perfect Tax. http://www.ft.com/cms/s/2/392c33a6-211f-11e3-8aff-00144feab7de.html.

Weber, R., Bhatta, S.D., Merriman, D., 2003. Does tax increment financing raise urban industrial property values? Urban Stud. 40 (10), 2001-2021.

Williams, R., Hallett, G., 1988. Great Britain. In: Hallet, G. (Ed.), Land and Housing Policies in Europe and the USA. Routledge, London, pp. 114-152.

\section{Legislation}

Declaration $n^{\circ} 376 / 99$ (Alteration of the Detail Plan of Caridade)

Decree law $\mathrm{n}^{\circ} 136 / 2014$ (Alteration of the juridical regime of urbanization and edification)

Decree law $n^{\circ} 80 / 2015$ (Juridical regime of territorial management instruments)

Federal Law 10257/2001 (Settles urban policy general guidelines, and other orders)

Governmental order $n^{\circ} 496 / 93$ (Detail Plan of Caridade)

Governmental order $n^{\circ}$ 633/95 (Urban Development Plan of Fátima)

Governmental order $n^{\circ} 190 / 97$ (Detail Plan of the Health Centre of Ourém)

Governmental order $n^{\circ} 445 / 97$ (Alteration of the Detail Plan of Caridade)

Governmental order $n^{\circ}$ 67/99 (Detail Plan for the block formed by Francisco Marto Road, Lomba de Égua Street and Market Road)

Law $\mathrm{n}^{\circ} 31 / 2014$ (Portuguese Land Territorial Ordering and Urbanism Act)

Legal warning $n^{\circ} 2766 / 2009$ (Simplified alteration of the Urban Development Plan of Fátima)

Legal warning $\mathrm{n}^{\circ} 5416 / 2009$ (Rectification of the Municipal Master Plan of Ourém)

Legal warning $\mathrm{n}^{\mathrm{o}} 18200 / 2009$ (New rectification of the Municipal Master Plan of Ourém and of the Urban Development Plan of Fátima)

Legal warning $\mathrm{n}^{\circ}$ 15622/2009 (Detail Plan of Avenue Pope John XXIII)

Legal warning $n^{\circ} 11779 / 2010$ (Adjustment of the Municipal Master Plan of Ourém to the Regional Plan of Territorial Ordering of West and Tagus Valley (PROTOVT)

Legal warning n. $.^{\circ} 7841 / 2011$ (Alteration in the rectification of the adjustment of the Municipal Master Plan of Ourém to the Regional Plan of Territorial Ordering of West and Tagus Valley (PROTOVT))

Legal warning $\mathrm{n}^{\mathrm{0}} 4735 / 2013$ (Alteration in the National Environmental Reserve map of Ourém)

Legal warning $n^{\circ} 4800 / 2013$ (Modification in the plan of Pias Longas site)

Legal warning $\mathrm{n}^{\circ} 6992 / 2015$ (Modification in the Urban Development Plan of Fátima)

Rectification declaration $n^{\circ}$ 1614/2010 (Rectification of the adjustment of the Municipal Master Plan of Ourém to the Regional Plan of Territorial Ordering of West and Tagus Valley (PROTOVT))

Rectification declaration $n^{\circ} 485 / 2015$ (new rectification of the Municipal Master Plan of Ourém)

Resolution $n^{\circ}$ 195/91 (Detail Plan of the industrial area of Casal dos Frades)

Resolution of the cabinet council $n^{\circ} 159 / 2000$ (Detail Plan of Quinta do Ribeirinho)

Resolution of the cabinet council $\mathrm{n}^{\mathrm{0}}$ 148-A/2002 (Municipal Master Plan of Ourém)

Resolution of the cabinet council $\mathrm{n}^{\circ}$ 148-B/2002 (Revision of the Urban Development Plan of Fátima)

Dutch Government Administration http://english.minfin.nl/Subjects/Taxation/A_brief outline_of_all_taxes_in_the_ Netherlands

German Law Archive; http://www.iuscomp.org

GNTL-Global Land Tool Network, http://www.gltn.net/http://www.gltn.net/

http://www.dgterritorio.pt/.

http://www.google.com

http://www.legislation.gov.uk

Noticias Juridicas, http://noticias.juridicas.com 